\title{
1 Role of PIF4 and FLC in controlling flowering time under daily 2 variable temperature profile
}

3 8

13 Thailand

14 '5ystems Biology of Diseases Research Unit, Faculty of Science, Mahidol University, Bangkok, Thailand 15 16

*Corresponding authors. E-mail: varodom.cha@mahidol.ac.th, wigge@igzev.de 7
Leibniz-Institut für Gemüse- und Zierpflanzenbau, Großbeeren, Germany

${ }^{5}$ Institute of Biochemistry and Biology, University of Potsdam, Potsdam, Germany

${ }^{6}$ Integrative Computational BioScience (ICBS) Center, Mahidol University, Nakhon Pathom 73170, 


\section{ABSTRACT}

Initiation of flowering is a crucial developmental event that requires both internal and environmental signals to determine when floral transition should occur to maximize reproductive success. Ambient temperature is one of the key environmental signals that highly influence flowering time, not only seasonally but also in the context of drastic temperature fluctuation due to global warming. Molecular mechanisms of how high or low constant temperatures affect the flowering time have been largely characterized in the model plant Arabidopsis thaliana; however, the effect of natural daily variable temperature outside laboratories is only partly explored. Several groups of flowering genes have been shown to play important roles in temperature responses, including two temperature-responsive transcription factors (TFs), namely PHYTOCHROME INTERACTING FACTOR 4 (PIF4) and FLOWERING LOCUS C (FLC), that act antagonistically to regulate flowering time by activating or repressing floral integrator FLOWERING LOCUS T (FT). In this study, we have demonstrated that the daily variable temperature (VAR) causes early flowering in both natural accessions Col-0, C24 and their late flowering hybrid C24xCol, which carries both functional floral repressor FLC and its activator FRIGIDA (FRI), as compared to a constant temperature (CON). The loss-of-function mutation of PIF4 exhibits later flowering in VAR, suggesting that PIF4 at least in part, contributes to acceleration of flowering in response to the daily variable temperature. We find that VAR increases PIF4 transcription at the end of the day when temperature peaks at $32^{\circ} \mathrm{C}$. The $F T$ transcription is also elevated in VAR, as compared to CON, in agreement with earlier flowering observed in VAR. In addition, VAR causes a decrease in FLC transcription in 4-week-old plants, and we further show that overexpression of PIF4 can reduce FLC transcription, suggesting that PIF4 might also regulate FT indirectly through the repression of FLC. To further conceptualize an overall model of gene regulatory mechanisms involving PIF4 and FLC in controlling flowering in response to temperature changes, we construct a co-expression - transcriptional regulatory network by combining publicly available transcriptomic data and gene regulatory interactions of our flowering genes of interest and their partners. The network model reveals the conserved and tissue-specific regulatory functions of 62 flowering-timerelating genes, namely PIF4, PIF5, FLC, ELF3 and their immediate neighboring genes, which can be useful for confirming and predicting the functions and regulatory interactions between the key flowering genes.

Keywords: flowering time, daily temperature variations, phytochrome interacting factor (PIF), FLOWERING LOCUS C (FLC) 


\section{1 | INTRODUCTION}

For the past decades, the global temperature has been fluctuating more drastically, at least in part as a result of global warming. This has major detrimental effects on all the living organisms around the world, especially plants. Since plants are sessile organisms, they are constantly exposed to environmental changes during day and night, as well as through different seasons. Thus, plants need to perceive the changes and adapt themselves to be able to respond rapidly, or face extinction. Flowering is an important developmental event in flowering plants as they need to integrate both internal and environmental factors to make an important decision on when floral transition should occur, in order to maximize reproductive success, and temperature is known to be one of the most important environmental cues that regulate flowering time (Capovilla et al., 2015; Halliday et al., 2003; Salome \& McClung, 2004).

Certain plants require prolonged exposure of cold to trigger flowering, known as vernalization. The model plant Arabidopsis thaliana are generally classified into the winter-annual and summer-annual ecotypes, according to the time of year and how their flowering is initiated. Many winter-annual ecotypes exhibit a late-flowering phenotype that requires vernalization during the winter to trigger flowering in the following spring, while the summer-annual ecotypes can flower rapidly without the requirement of vernalization. The differences in flowering behaviors can largely be explained by the genetic variations in the genes FLOWERING LOCUS C (FLC) and FRIGIDA (FRI) (Clarke \& Dean, 1994; Johanson et al., 2000; Koornneef et al., 1994; Lee et al., 1993; Michaels \& Amasino, 1999; Shindo et al., 2005). Most of the lateflowering winter-annual ecotypes possess the strong (also referred to as "active" or "functional") alleles of $F L C$ and $F R I$. In contrast, most of the early-flowering summer-annual ecotypes contain either or both the weak (also known as "inactive" or "nonfunctional") alleles of the two genes. However, strong alleles of FLC and $F R /$ from different early-flowering plants could give rise to late flowering phenotypes when they are combined, such as in hybrid plants.

Sanda and Amasino have previously shown that the F1 plants from crossing the C24 with Col-0 ecotypes, which contain strong alleles of $F R /$ and $F L C$ from C24 and Col-0, respectively, flowered extremely late in relative to either parental ecotype (Sanda \& Amasino, 1995). FRI, which functions as an upstream regulator of $F L C$, activates the transcription of $F L C$ through forming the transcription activator complex FRI$C$ with the other four proteins, namely FRL1, FES1, SUF4 and FLX, to recruit chromatin modification factors and other general transcription factors (TFs) to the promoter of FLC (Choi et al., 2011; Michaels \& Amasino, 
1999). The FLC gene itself, which encodes a MADS-box TF, acts as a repressor of flowering by suppressing transcription of the floral integrator gene, FLOWERING LOCUS T (FT) (Michaels \& Amasino, 1999; Searle et al., 2006). FT encodes a mobile signal called "florigen", which transmits the information from leaves to shoot apical meristem to promote floral transition (Jaeger \& Wigge, 2007). However, FLC transcription can be repressed by vernalization, which promotes the epigenetic silencing of $F L C$ through the recruitment of the PHD-PRC2 complex to specific regions of FLC and depositing H2K27me3 repressive marks, leading to stable repression of FLC (Sheldon et al., 2000; Song et al., 2012). Thus, during the winter, vernalization of the winter-annual ecotypes can trigger floral transition in the following spring through epigenetic repression of $F L C$ transcription.

In addition to vernalization, low and high ambient temperatures are among other temperature signals that highly influence flowering time. In laboratory conditions, constant temperatures of $22-23^{\circ} \mathrm{C}$ are commonly used for growing the model plant Arabidopsis thaliana (Rivero et al., 2014). However, the plants showed delayed and accelerated flowering when grown under a constant low temperature at $16^{\circ} \mathrm{C}$, or high ambient temperature at $25^{\circ} \mathrm{C}$ or $27^{\circ} \mathrm{C}$, respectively (Balasubramanian et al., 2006; Blazquez et al., 2003; Samach \& Wigge, 2005). For an elevated temperature, it has been shown that the accelerated flowering was mainly linked to the increased expression of FT (Balasubramanian et al., 2006). One of the key regulators of $F T$ is PHYTOCHROME-INTERACTING FACTOR 4 (PIF4), a basic helix-loop-helix (bHLH) TF, which also plays an important role in morphological changes in response to high ambient temperature, including petiole elongation, leaf hyponasty and hypocotyl elongation (Franklin et al., 2011; Gray et al., 1998; Koini et al., 2009; Sun et al., 2012). PIF4 also contributes to the induction of flowering under high ambient temperature under the short-day photoperiod (Kumar et al., 2012; Fernandez et al., 2016). However, this positive effect of PIF4 on reducing flowering time appears to be dependent on photoperiod, as the loss-offunction mutant of PIF4 in pif4-101, grown at $28^{\circ} \mathrm{C}$ under constant light, flowered with nearly the same leaf number as in wild-type, WT (Koini et al., 2009). PIF4's close homolog, PIF5 (also known as PIL6), has also been shown to play a redundant role with PIF4 in regulating hypocotyl elongation and flowering time (Fujimori et al., 2004; Kunihiro et al., 2011; Nusinow et al., 2011; Thines et al., 2014).

PIF4 and PIF5 are transcriptionally regulated by circadian clock (Nozue et al., 2007), where the PIF4/PIF5 proteins are degraded by the light-activated phytochrome B (phyB)-dependent mechanism (Lorrain et al., 2008; Niwa et al., 2009). During early night, the transcription of PIF4 and PIF5 is directly repressed by the evening complex (EC), an essential component of the circadian clock, comprising EARLY 
FLOWERING 3 (ELF3), EARLY FLOWERING 4 (ELF4) and LUX ARRHYTHMO (LUX), whose expressions peak at the end of day (Huang \& Nusinow, 2016; Nusinow et al., 2011). Towards the end of night, the level of EC decreases, allowing the mRNA and protein of PIF4/PIF5 to accumulate, and this promotes hypocotyl growth at dawn. Interestingly, it has been shown that EC binds to its targets in a temperature-dependent manner, as the binding of EC to its targets, including PIF4, markedly reduces at high ambient temperature $\left(27^{\circ} \mathrm{C}\right)$ (Box et al., 2015; Ezer et al., 2017; Silva et al., 2020). Transcript level of PIF4 itself has been shown to increase as the temperature goes up from low to high ambient (Kumar et al., 2012; Mizuno et al., 2014), as well as its ability to bind to the FT promoter and activate the floral integrator gene (Kumar et al., 2012).

Despite a large body of knowledge of the molecular mechanisms of temperature-dependent flowering time control, the vast majority of the findings have been obtained in laboratory conditions using constant temperatures, or with two different temperatures during the day and night. This artificial growth environment might not be able to comprehensively represent natural conditions, where the temperature gradually rises and declines during the day and night (Wilczek et al., 2009). For this reason, Burghardt and coworkers (Burghardt et al., 2016) have adopted a variable temperature condition, where temperature profile was designed to mimic daily fluctuating temperature conditions in the real environment, and investigated its effect on flowering time. They demonstrated that this daily variable temperature condition could shorten flowering time, especially in the late-flowering plants with high FLC expression. In addition to FLC, other genes that appeared to contribute to the accelerated flowering under the variable temperature profile include CONSTANS (CO), GIGANTEA (GI), FT, and PHYB, suggesting that the early flowering might not be modulated by floral repression through FLC alone. Interestingly, despite their welldocumented functions in temperature-dependent flowering-mediating pathways, the potential involvement of PIFs in early flowering in this variable temperature condition has not been addressed. In addition, the PIF genes have been shown to be important for shade avoidance responses, such as hypocotyl elongation, leaf hyponasty (Lorrain et al., 2008; Nozue et al., 2015), the same phenotypes that were also strongly observed in the early flowering plants under the variable temperature condition (Burghardt et al., 2016).

In this study, we aimed to further investigate the flowering time of plants grown under the variable temperature condition that mimics daily variable temperature pattern (VAR), as used by Burghardt and colleagues (Burghardt et al., 2016), by focusing on FLC and PIF4, two key flowering genes known to be involved in temperature-dependent flowering regulation through the floral integrator FT. We first 
bioRxiv preprint doi: https://doi.org/10.1101/2020.10.22.348540; this version posted October 22,2020 . The copyright holder for this preprint (which was not certified by peer review) is the author/funder, who has granted bioRxiv a license to display the preprint in perpetuity. It is made available under aCC-BY-NC-ND 4.0 International license.

investigated if and to what extent, PIF4 contributed to the acceleration of flowering under the VAR condition in natural Arabidopsis thaliana lines with strong and weak alleles of FLC and FRI, namely Col-O, $\mathrm{C} 24$, and their extremely late flowering hybrid, C24xCol-0. To gain a bigger picture of how these flowering time regulatory circuit changes with temperature, we gathered and utilized publicly available Arabidopsis transcriptomic data obtained from different growth temperatures and tissues, to explore transcriptional profiles of PIF4, PIF5, FLC, ELF3, which play a role in different but overlapping flowering pathways, as well

149 as their immediate up- and downstream regulatory genes, under different temperature and light 150 conditions. We also constructed a combined co-expression - transcriptional regulatory network by 151 integrating characterized gene regulatory information with transcription patterns, which is used to 152 investigate the dynamics and interplay among these key flowering genes in different temperatures and 153 tissues. 


\section{2 | MATERIALS AND METHODS}

\section{1 | Plant materials and growth conditions}

160

To investigate the potential role of PIF4 in acceleration of flowering under the daily variable temperature condition (VAR, herein) in natural Arabidopsis thaliana lines with strong and weak alleles of FLC and FRI, Arabidopsis seeds were stratified in 0.1\% 1/2 MS (Murashige and Skoog 1962) agar solution and kept in the dark at $4^{\circ} \mathrm{C}$ for 3 days to promote germination. After stratification, the seeds were sown in compost (Levington's F2) and grown in growth chambers (MLR 351, SANYO Electric Co., Ltd.) under cool-white fluorescent light (intensity of approximately $140-160 \mu \mathrm{mol} \mathrm{m} \mathrm{m}^{-2}$ ) in the short-day (SD) photoperiod (8 $\mathrm{h}$ light/16 $\mathrm{h}$ dark) at either constant temperature, $\operatorname{CON}\left(22^{\circ} \mathrm{C}\right)$, or variable temperature, $\operatorname{VAR}\left(22^{\circ} \mathrm{C}\right.$ on average) (Figure 1a). The variable temperature profile was obtained from the previous study by Burghardt and coworkers (Burghardt et al., 2016). This part of the experiment was performed at Sainsbury Laboratory Cambridge University, UK.

The interplay between PIFs and their regulators, namely the evening complex (EC), and its effect on the flowering time were assessed using the mutants pif4-101, elf3-2, pif4.pif5, pif4-101 elf3-2 double mutant, and pif4.pif5 elf3-2 triple mutant, which are all in the Columbia-0 (Col-0) background. All the Arabidopsis seeds were gifts from the Wigge laboratory, Sainsbury Laboratory. The pif4-101 elf3-2 double mutant and pif4.pif5 elf3-2 triple mutant were originally generated by Nusinow and coworkers (Nusinow et al., 2011). Seeds were stratified in $0.1 \%$ agar solution in the dark at $4^{\circ} \mathrm{C}$ for 3 days, and sown in pots containing soil mixture (Peat moss : Perlite : Vermiculite, 3:1:1). Plants were grown on a shelf in an airconditioned walk-in room with the light intensity of approximately $70-80 \mu \mathrm{mol} \mathrm{m} \mathrm{s}^{-2}$ under cool-daylight fluorescent light (PHILIPS TL-D 36W/54-765) at a constant temperature $\left(22 \pm 1^{\circ} \mathrm{C}\right)$ in short-day (SD) photoperiod ( $8 \mathrm{~h}$ light/16 h dark). This part of the experiment was performed at Mahidol University, Thailand.

\section{2 | Flowering time measurement}

Arabidopsis seeds were stratified and grown under constant (CON) and variable (VAR) temperature conditions in the short-day (SD) photoperiod as described above. We measured the flowering time by the rosette leaf number and number of days to flower when the inflorescence was about $1 \mathrm{~cm}$ in length, as they are commonly used as flowering time indicators (Pouteau and Albertini, 2009). 


\section{3 | RNA extraction and quantitative real-time PCR}

188 Transcription levels of the flowering genes of interest, namely AT2G43010 (PIF4), AT5G10140 (FLC) and 189 AT1G65480 (FT), were assessed using RT-qPCR of the rosette leaf samples from 10-day-old or 28-day-old plants grown under the constant (CON) and variable temperature (VAR) conditions. The samples were harvested at ZTO (dawn) and ZT8 (dusk). RNA was extracted from the leaf samples using the 96-well plate protocol as described by Box and coworkers (Box et al., 2011). Total RNA was treated with DNase I (Ambion,

193 USA) to remove contaminating genomic DNA. DNase-treated RNA was then used for CDNA synthesis (Roche

194 Molecular Systems, Inc.), and quantitative PCR (qPCR) was performed using SYBR Green master mix, and 195 the Roche Lightcycler 480 II instrument. The oligonucleotide primers used in this study are listed in Table 196 S1. To measure the PIF4 transcript levels, two primer pairs PIF4_6981/PIF4_6982, and 197 PIF4_6581/PIF4_6582 were used to amplify different regions of the PIF4 gene. The 6981-6982 primers 198 amplify across the T-DNA junction, which confirms the presence or absence of T-DNA insertion at PIF4 in 199 the pif4-101 line, whereas the primers 6581-6582 amplify a region upstream to the T-DNA insertion site. 200 AT5G25760 (PEX4) and AT2G28390 (a SAND family protein) were used as reference control genes, as in 201 previous studies (Czechowski et al., 2005; Hong et al., 2010). To investigate the interplay between PIF4/PIF5 202 and evening complex (EC) in regulating flowering time, transcription levels of key flowering genes, namely 203 AT2G43010 (PIF4), AT3G59060 (PIF5) and AT1G65480 (FT), the samples were collected from the 28-day204 old plants grown at $\operatorname{CON}\left(22 \pm 1^{\circ} \mathrm{C}\right)$ as described above. The aerial parts were harvested at ZTO (dawn) and ZT8 (dusk), and were manually ground in liquid nitrogen and RNA was extracted using Trizol Reagent (Invitrogen, USA), following the manufacturer's instruction. Removal of contaminating genomic DNA and CDNA synthesis were performed using ReverTra Ace ${ }^{\circledR}$ qPCR RT Master Mix with gDNA remover (TOYOBO CO., LTD, Japan). Transcript expression was determined by qPCR using THUNDERBIRD SYBR qPCR mix (TOYOBO CO., LTD, Japan) on the M×3000P qPCR system (Agilent technologies, USA). For this experiment, PIF4 transcription levels were analyzed using the primers PIF4_6981/PIF4_6982. To detect FT transcription

211 levels, the primers FT_7380/FT_7381 were used. AT2G28390 (a SAND family protein) was used as a 212 reference control gene.

\section{$213 \quad 2.4$ | Data and statistical analyses}

214 The total number of days to flowering, the total number of rosette leaves at the flowering days and 215 transcript levels of the flowering genes of interest were displayed as box plots using the "ggplot2" package 216 in the R statistics (R Core Team, 2019) via R studio (https://www.rstudio.com). A minimum of three 217 biological replicates, each with three technical replicates were performed for the GPCR analysis. The 
relative expression was calculated using comparative $C p$ method $(\Delta \Delta C p)$. The averaged $C p s$ of the reference genes, AT5G25760 (PEX4) and AT2G28390 (a SAND family protein) of each sample were used as controls for normalization, and the transcriptional levels from individual biological replicates were normalized again to the averaged transcriptional levels of the reference samples (normally Col-0 grown in the CON condition at ZTO, unless stated otherwise). Statistical tests between the two groups of interest were computed by Wilcoxon rank sum test using the stat_compare_means() function in the "ggpubr" package.

\section{5 | Analyzing and visualization of flowering gene transcriptomes}

The list of immediate up- and downstream flowering genes of PIF4, PIF5, ELF3 and FLC were extracted from the Flowering Interactive Database (FLOR-ID) (Bouche et al., 2016). Out of all 306 characterized flowering genes in FLOR-ID, our sub-network contains 62 flowering genes (PIF4, PIF5, ELF3, FLC and their 1st degree neighboring genes) (Table S2) and 128 interactions (Table S7). The transcriptional profiles of these flowering genes were extracted from 152 publicly available RNA-seq experiments of Arabidopsis thaliana ecotype Col-0 from 10 different studies across five different tissue types: whole seedling, rosette leaves, mature pollen grain, root and shoot apical meristem (Table S3), where the plants were treated with various temperature conditions. The RNA-seq datasets were re-analyzed and re-normalized to transcripts per million (TPM) values. To compare the transcript expression patterns between the different experimental conditions, the TPM values of each gene were Z-score transformed across either all tissues (152 samples), or across individual tissues, using the "matrixStats" package in the R statistics (R Core Team, 2019). The Zscore matrix was visualized as a heat map using the Heatmap() function in the "ComplexHeatmap" package.

\section{6 | Constructing co-expression - gene regulatory network of flowering time mechanism}

238 The immediate up- and downstream flowering genes (1st degree neighboring genes) to the flowering-time239 relating genes of interest, namely PIF4, PIF5, ELF3, FLC, were obtained from the FLOR-ID database (Bouche 240 et al., 2016) as described above. Normalized TPM values of transcriptomes were used to calculate the 241 correlation coefficients of transcript levels between each gene pair of 62 flowering genes across all 242 conditions, and either across the five tissues or for individual tissues. The Spearman's correlation 243 coefficients were computed using the cor() function in the "ggcorrplot" package in the R statistics (R Core

244 Team, 2019). For individual tissues, the correlation coefficient over the cutoff threshold of $+/-0.10$ was 245 considered significant, and used in further analysis. We then integrated the correlation coefficient values 246 of individual gene pairs and the gene regulatory information from literature (i.e. activating or repressing 
bioRxiv preprint doi: https://doi.org/10.1101/2020.10.22.348540; this version posted October 22,2020 . The copyright holder for this preprint (which was not certified by peer review) is the author/funder, who has granted bioRxiv a license to display the preprint in perpetuity. It is made available under aCC-BY-NC-ND 4.0 International license.

regulatory function), to construct a combined co-expression - transcriptional regulatory network, which was visualized using Cytoscape v3.7.1 (Shannon et al., 2003).

249

250 


\section{3 | RESULTS AND DISCUSSION}

\subsection{Daily variable temperature accelerates flowering in Arabidopsis thaliana Col-0, C24 and their late}

\section{flowering hybrid $\mathrm{C} 24 \times \mathrm{Col}$}

Arabidopsis thaliana ecotypes Col-0, C24, and their late flowering hybrid, C24xCol-0 were grown at either constant temperature of $22^{\circ} \mathrm{C}(\mathrm{CON})$ or variable temperature (VAR) with the average of $22^{\circ} \mathrm{C}$, as used in the earlier study by Burghardt and coworkers (Burghardt et al., 2016). The variable condition was designed to simulate the daily temperature variation, rising and falling between $12^{\circ} \mathrm{C}$ and $32^{\circ} \mathrm{C}$, in the short-day (SD) photoperiod (Figure 1a). Phenotypic differences including leaf shape and petiole elongation were observed in the VAR condition (Figure S1). We have shown that both wild-type Col-0 and C24 grown in the VAR condition flowered earlier than those grown in the CON condition (Figure 1c). Consistently with the flowering time measured by the number of days to flowering, plants grown under VAR produced fewer rosette leaves (Figure 1d), as the plants spent less time in vegetative phase. Our second replicate (the two biological replicates were independent and were carried out separately at different times) also confirmed these trends (Figure S2). In the CON temperature condition, the F1 hybrids of C24xCol had more rosette leaves than both parental ecotypes when flowered, which was consistent with the previous study by Sanda and Amasino (Sanda \& Amasino 1995). Interestingly, we observed that the delay of flowering in the hybrids were more prominent in terms of number of leaves than the number of days to flower (Figure 1d, blue boxes). As expected, C24xCol grown under VAR exhibited early flowering as compared to CON (Figure 1b, $c$ and d), confirming that the variable temperature condition (VAR) can accelerate transition to flowering in the natural ecotypes of Arabidopsis thaliana Col-0, C24, as well as their late flowering hybrid, C24xCol.

\section{2 | PHYTOCHROME INTERACTING FACTOR 4 (PIF4) contributes to early flowering in daily variable} temperature condition

Elevated ambient temperature is generally known to promote transition of the vegetative stage to flowering, and this phenomenon is mediated by several molecular mechanisms (see a review by Capovilla et al., 2014). In particular, previous studies revealed that accelerated flowering in warm temperature requires the activity of the bHLH TF PIF4 (Kumar et al., 2012, Thines et al., 2014). To assess whether PIF4 also contributes to earlier flowering observed in Col-0 and the late flowering hybrid $\mathrm{C} 24 \times \mathrm{Col}$ under the daily-temperature mimicking condition (VAR), we investigated the flowering time of pif4-101 and C24xpif4101, which lack two copies and one copy of functional PIF4, respectively. Under the VAR condition, the 
number of days to flowering of the pif4-101 mutant was longer as compared with that of Col-0, and the difference between VAR and CON of the mutant was less than that of the wild type (Figure $1 c, d$ ). The difference between VAR and CON was even less in terms of the leaf numbers, where pif4-101 grown in VAR flowered with nearly the same leaf number as those grown in CON (Figure 1d). This trend was also clearly observed in the second replicate in terms of leaf numbers, but less so for the number of days (Figure S2). Similarly, C24xpif4-101 grown under VAR produced more rosette leaves and required longer time to flower than $\mathrm{C} 24 \mathrm{xCol}$ (Figure 1c, d), suggesting the loss of functional PIF4, even in only one copy from Col-0, out of the two from each parental ecotype, partly contributed to the reduced flowering time acceleration in the VAR condition as compared to CON. However, the pif4-101 and C24xpif4-101 mutants grown in VAR still flowered slightly earlier than those grown in CON (Figure 1c, $d$ and Figure S2), indicating that the variable temperature condition was still able to accelerate flowering in the full or partial absence of PIF4 activity. Thus, apart from PIF4, other regulators, including other paralogous PIF genes, might also contribute to accelerated flowering in response to the condition mimicking daily variable temperature.

\section{3 | Daily variable temperature can alter transcription levels of key flowering genes}

To investigate the molecular mechanism of how PIF4 accelerates flowering time under VAR, in conjunction with the known key flowering genes of FLC and FT, the transcription levels of PIF4, FLC and FT were determined at 10- and 28-day after sowing (DAS), in the plants grown under CON and VAR, at two timepoints: ZTO (dawn) and ZT8 (dusk). In all the Arabidopsis lines tested, with an exception of pif4-101, PIF4 transcription was higher in elevated ambient temperatures (Figure 2a, b), which is consistent with previous studies (Box et al., 2015; Kumar et al., 2012; Mizuno et al., 2014; Nomoto et al., 2013). At 10 DAS, PIF4 transcription in CON (constant $22^{\circ} \mathrm{C}$ ) was higher than in VAR $\left(12^{\circ} \mathrm{C}\right.$ at dawn, ZTO); whereas it was lower in $\operatorname{CON}\left(22^{\circ} \mathrm{C}\right)$ than in VAR $\left(32^{\circ} \mathrm{C}\right.$ at dusk, ZT8) (Figure 2a). The magnitudes of these differences appeared to be smaller as the plants became older (28 DAS); however, the same pattern of PIF4 transcription remained (Figure 2b). The elevated transcription levels of PIF4 in VAR as compared to CON at dusk, especially in the young seedlings (10 DAS), could potentially account for the early flowering seen in VAR. The might also be linked to the reduced DNA-binding activity of the evening complex (EC), hindering its repressing function of the PIF4 expression during warm night (Box et al., 2015; Ezer et al., 2017; Nusinow et al., 2011; Silva et al., 2020). The same results were confirmed using a separate primer set (Figure S3).

For $F L C$, its transcription level was higher in $\mathrm{C} 24$ and $\mathrm{C} 24 \mathrm{x} \mathrm{Col}$, where both contain a strong allele of $F R I$ that can activate FLC expression, as compared to in Col-0 (Figure 2c, d). Interestingly, although FLC transcriptions appeared to be comparable at ZTO and ZT8 in the 10 DAS plants grown at constant $22^{\circ} \mathrm{C}$ 
(Figure 2c, blue box plots), the same plants grown under VAR showed lower FLC transcription in the morning (ZTO) where the temperature was relatively low $\left(12^{\circ} \mathrm{C}\right)$, and higher when the temperature was high $\left(32^{\circ} \mathrm{C}\right)$ at dusk (ZT8) (Figure $2 \mathrm{c}$, green box plots). The suppressed transcription of $F L C$ in the chilly morning $\left(12^{\circ} \mathrm{C}\right)$ of VAR might partly be due to vernalization response, as a previous study has shown that vernalization can already occur in the constant $13{ }^{\circ} \mathrm{C}$ temperature condition (Wollenberg \& Amasino, 2012), although this "partial" vernalization alone could not account for the early flowering observed (Burghardt et al., 2016). At 28 DAS, the overall transcription level of FLC in C24 and C24xCol, as compared to that of Col-0, was reduced (from approximately 10-20 times higher than Col-0 at 10 DAS, to 5-10 times higher than Col-0 at 28 DAS) (Figure 2c, d). Importantly, FLC transcription of C24 and C24xCol grown under VAR was lower than CON in the 28 DAS plants at both ZTO and ZT8, indicating that suppression of FLC is one potential pathway that promotes early flowering in VAR, which might be the effect of partial vernalization as described above (Figure $2 \mathrm{~d}$ ). The transcript levels of $F T$, a flowering integrator downstream to both PIF4 and $F L C$, appeared to be increased in plants grown under the VAR condition in Col-0, C24, and their hybrid, especially at ZT8 (Figure S4), suggesting that FT-dependent pathway was likely to be one of the pathways that contributed to earlier flowering in response to the variable temperature. As previously reported, loss of $F T$ function resulted in delayed flowering under VAR condition in Ler but not in Col-0 background thus, this seemed to depend on the genetic background of plants (Burghardt et al., 2016). Our findings indicated that the acceleration of flowering time of plants grown in the variable temperature condition might, at least in part, be related to the suppression of $F L C$ and elevated expression of the FT gene in VAR.

\section{4 | Overexpression of PIF4 can reduce the effect of late-flowering phenotype under both constant and} variable temperature conditions

333 In the variable temperature (VAR) profile, PIF4 partly contributes to accelerating floral transition, potentially through its elevated expression at the warm temperature $\left(32^{\circ} \mathrm{C}\right)$ at the beginning of the night. This effect is especially prominent in $\mathrm{C} 24 \times \mathrm{Col}$, the late-flowering hybrid plant carrying strong alleles of $F L C$ and FRI. Here, we focused on the effect of elevated PIF4 expression on the flowering time of this lateflowering hybrid, using C24 crossed to heterozygous 355::PIF4 (in Col-0 background). A half of these F1

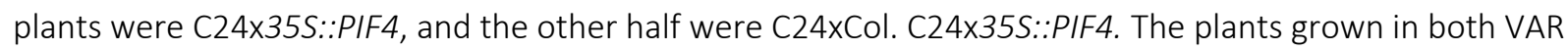
and CON flowered much earlier than C24xCol (Figure 3a), and the same trend was seen in terms of the leaf numbers (Figure 3b). However, VAR further reduced flowering time in C24×35S:PIF4 compared to CON

341 (Figure 3a, b). Kumar and coworkers previously found that floral acceleration by 35S::PIF4 relied on FT 
than C24x35S::FT in VAR (Figure 3a), whereas the number of days to flowering were indistinguishable between C24×35S::FT grown in CON and VAR (Figure 3a, b). These together indicate that apart from PIF4, other regulators also contribute to the earlier flowering time in VAR, which might also be dependent on FT.

We further sought to explore the mechanism of how the overexpression of PIF4 accelerates the flowering time in the late flowering C24xCol. Transcriptional analysis by RT-qPCR showed that PIF4 transcript level in C24×35S::PIF4 in CON was indeed higher than that of C24×Col as expected, and also led to higher FT transcription (Figure 3c, e). Interestingly, we found that $F L C$ transcription levels appeared to be reduced in C24×35S::PIF4 at 10 DAS (Figure 3d) as well as at 28 DAS (Figure S5). Since FLC has been identified as a downstream target of PIF4 using ChIP-seq (Oh et al., 2012), it is possible that that overexpressed PIF4 binds to its cognate sites at the FLC promoter and suppresses its transcription. Along this line, the transcription levels of FLC of pif4-101 were slightly higher than those of Col-0 in both CON and VAR (Figure 2c, d). On the other hand, the elevated expression of PIF4 in C24xCol in VAR at ZT8 $\left(32^{\circ} \mathrm{C}\right.$ ), as compared to that in $\mathrm{CON}$ at $\mathrm{ZT8}\left(22^{\circ} \mathrm{C}\right)$ (Figure 2a), was not sufficient to suppress $F L C$ within a short time

356 frame at 10 DAS (Figure 2c), but might play a part in suppression of FLC over a longer period of time as seen 357 at 28 DAS (Figure $2 \mathrm{~d}$ ).

\section{5 | ELF3 may bypass PIF4/PIF5 to delay flowering transition through other regulators}

Having investigated the interplay between the key flowering genes PIF4, FLC, and FT and their roles in accelerating flowering time in the daily fluctuating temperature mimicking condition, here we looked to further explore the interactions of these genes and their "immediate" neighbours in the gene regulatory network. We focused on PIF5, a close homolog to PIF4, and the evening complex (EC), which directly binds to the promoters of PIF4 and PIF5 and represses their transcription in the early evening (Nusinow et al., 2011). It has been shown in the mutant elf3-2, which carries non-functional ELF3, a gene encoding for a component of the EC complex together with ELF4 and LUX, displayed elongated hypocotyl at constant $22^{\circ} \mathrm{C}$. However, this phenotype was suppressed in the elf3-2 pif4-101 double mutant and elf3-2 pif4.pif5 triple mutant, which showed the normal hypocotyl lengths as seen in Col-0 (Nusinow et al., 2011). Here, we asked if and to what extent the interplay between PIF4/PIF5 and the evening complex (EC) also affects the flowering time.

We grew Col-0, pif4-101, elf3-2, pif4.pif5 double mutant, pif4-101 elf3-2 double mutant and pif4.pif5 elf3-2 triple mutant in constant temperature condition $\left(22 \pm 1^{\circ} \mathrm{C}\right)$ for flowering time measurement, and transcript level analyses using RT-qPCR of the 28 DAS plants at two time-points: ZTO and ZT8. 
the pif4-101 mutant led to delayed flowering as compared to Col-0, and loss of both PIF4 and PIF5 in the pif4.pif5 mutant led to even longer time to flower (Figure 4a) in the short day photoperiod. This indicates that PIF4 and PIF5 play a partially redundant role in flowering regulation, as previously shown by Thines and coworkers in the 12/12 $\mathrm{h}$ light/dark condition (Thines et al., 2014).

The elf3-2 mutant flowered much earlier and had fewer rosette leaves at the flowering days than Col-0 (Figure 4a, b). As the evening complex (EC) cannot be formed in the absence of ELF3 (Nusinow et al., 2011), we observed increased transcription levels of PIF4 and PIF5 in the elf3-2 mutant (Figure 4c, d). The loss of either PIF4 or both PIF4 and PIF5 in the pif4-101 and pif4.pif5 mutants, respectively, resulted in slightly higher transcription of FLC as compared to Col-0 (Figure 4e) and this is similar to what was observed previously (Figure 2c). Along the same line, the loss of ELF3 in the elf3-2 mutant showed elevated transcription of PIF4 and PIF5, leading to higher transcription of FLC than in Col-0. However, there was no clear difference observed in the FLC transcription levels of the elf3-2 mutant, the pif4-101 elf3-2 double mutant and the pif4.pif5 elf3-2 triple mutant, suggesting the evening complex or ELF3 alone, might also repress FLC transcription in an PIF4/PIF5-independent manner (Figure 4e). Interestingly, FT transcription levels at ZT8 were highly accumulated in the elf3-2, pif4-101 elf3-2, and pif4.pif5 elf3-2 plants, as compared to that in Col-0 (Figure 4f). The higher FT accumulation could be at least in part, due to the increased expression of PIF4 and PIF5, activators of FT transcription (Thines et al., 2014). Transcription level of PIF5 in the pif4-101 elf3-2 double mutant was lower than in the elf3-2 mutant, but still higher than in Col-0 (Figure 4d). Since the previous ChIP-seq study showed that PIF5 was a direct target of PIF4 (Oh et al., 2012), the lower transcription of PIF5 observed in the pif4-101 elf3-2 mutant is likely due to lack of PIF4 activity, which is partly required for transcriptional activation of PIF5.

Transcription level of $F T$ was highest in elf3-2, followed by the pif4-101 elf3-2 double mutant and pif4.pif5 elf3-2 triple mutant (Figure 4f). However, the FT transcription level in the triple mutant remained higher than in Col-0. These, together with the flowering time results (Figure $4 a, b$ and f), indicate that ELF3 (and possibly EC) regulates FT expression and flowering time partly through PIF4 and PIF5, but might also repress the transcription of $F T$ directly or through different regulators, such as other PIF genes, resulting in the delay in transition to flowering.

\section{6 | Temperature transcriptomic profiles of flowering genes in different plant tissues}

403 Making used of publicly available transcriptomic data, we further expanded our investigation of the 404 transcriptional relationship among the flowering-time-relating genes of interest, namely PIF4, PIF5, ELF3, 
Database (FLOR-ID) (Bouche et al., 2016) (Table S2, see Methods), under different temperature conditions (low temperature, normal temperature, high temperature, temperature shift and heat shock), different light conditions (short-day photoperiod and long-day photoperiod) and different tissue types (whole seedling, rosette leaves, mature pollen grain, root and shoot apical meristem) (see Table S3 for complete information of transcriptomic datasets obtained). In total, we extracted 62 flowering-time-relating genes (PIF4, PIF5, ELF3, and FLC and their immediate neighbours) from the Flowering Interactive Database (FLORID) (Bouche et al., 2016) (Table S2, see Methods), and their transcriptional levels from 152 RNA-seq experiments (Cortijo et al., 2017; Dickinson et al., 2018; Durufle et al., 2017; Ezer, Jung, et al., 2017; Ezer, Shepherd, et al., 2017; Martins et al., 2017; Pajoro et al., 2017; Rahmati Ishka et al., 2018; Tasset et al., 2018; Zhu et al., 2015) (Table S4).

The overall transcriptional patterns of the 62 flowering genes of interest under different temperature conditions were largely grouped by the tissue types (Figure 5a), and perhaps unsurprisingly, the transcriptional patterns of shoot apical meristem (SAM) stands out from the rest of the plant. More specifically, the genes in Cluster 3 (e.g. ELF3, FCA, FRI) were relatively up-regulated in SAM and root; whereas the genes in Cluster 4 (e.g. FD, SOC1, SPL15) appeared to be specifically up-regulated in SAM. This falls in line with earlier studies showing that FD is strongly expressed in SAM, and the FD protein interacts with the floral integrator $F T$, to activate the expression of another floral integrator SOC1 in SAM, to promote floral transition (Abe et al., 2005; Searle et al., 2006; Wigge et al., 2005). SPL15 also functions together with SOC1 to activate their target genes and promote flowering transition (Hyun et al., 2016).

We next explored the effect of the temperature conditions on these flowering genes of interest in individual tissues (Figure 5b, c and Figure S6-8). For SAM, transcriptomic patterns of these genes were extracted from 30 RNA-seq experiments published by Pajoro and coworkers (Pajoro et al., 2017) and renormalized by us (Figure 5b). In that study, the plants were grown at $16^{\circ} \mathrm{C}$ for 5 weeks and either kept at $16^{\circ} \mathrm{C}$, or transferred to $25^{\circ} \mathrm{C}$. The genes in Cluster 1 were largely up-regulated at the constant low temperature, including TOE1, GI, PRR7 (Figure 5b). On the other hand, Clusters 2 and 3 were both largely up-regulated in the plants shifted to $25^{\circ} \mathrm{C}$, except that the Cluster 2 genes (e.g. FCA, PIF4, RGL2) were upregulated within 1 day after the temperature shift and remained highly transcribed after 3 and 5 days; whereas the Cluster 3 genes (e.g. ELF7, SPT16, GASA5) showed slower activation after 3 days of the temperature shift. Interestingly, there are some genes in Cluster 3 that were up-regulated at low temperature and then transiently down-regulated at day 1 after the shift, and returned to the original levels within 3 days, namely ICE1, PIE1 and CLF (see Table S5 for a complete list of genes in different clusters in SAM). 
The transcriptomic patterns of these flowering genes in root were derived from the study by Martins and coworkers (Martins et al., 2017), where the plants were grown at constant $21^{\circ} \mathrm{C}$ or $26^{\circ} \mathrm{C}$ for 10 days. Interestingly, several known flowering genes were up-regulated not only in SAM but also in root. This includes FCA, which encodes an RNA-binding protein that acts as a positive regulator of flowering. Interestingly, it has been shown that FCA also plays a regulatory role in root development, and loss of its function in an fca mutant led to shorter root lengths and reduced numbers of lateral roots (Macknight et al., 2002). We observed that the genes in Cluster 1 of the root transcriptomic heatmap, including FCA, were up-regulated in response to the elevated temperature $\left(27^{\circ} \mathrm{C}\right)$ (Figure $5 \mathrm{C}$ ). In contrast, the genes in Cluster 4 (i.e. FLC, FD, SOC1) appeared to be relatively down-regulated at $27^{\circ} \mathrm{C}$ and up-regulated at $21^{\circ} \mathrm{C}$. Despite the two studies being conducted using different temperature settings, it is still intriguing to see a number

448 of genes being activated by higher ambient temperatures in both SAM and root (e.g. FCA, LUX, ELF7), as 449 well as those appeared to be specifically activated by heat in SAM (e.g. SPL15, GASA5, CSTF64), or in root 450 (e.g. ELF4, UGT87A2, RVE8) (see Table S6 for a complete list of genes in different clusters in root).

\section{7 | A combined co-expression - gene regulatory network dissects conserved and tissue-specific} regulatory functions of key flowering genes

453 Finally, we asked if and how the transcriptomic profiles of the flowering genes described in the previous section could be linked to their types of regulatory functions (i.e. activator and repressor), based on the characterized interactions from the Flowering Interactive Database (FLOR-ID), as well as additional evidence from literature (see Table S7 for details). We computed the Spearman's rank correlation coefficients, $\rho$ ("rho"), of transcriptional patterns of the each gene pair among the 62 flowering genes of interest here, and overlaid them onto the 128 regulatory interactions connecting these genes from FLORID, to construct a combined co-expression - transcriptional regulatory network (Figure 6a, and a Cytoscape session file (.cys) is also provided as an Additional File). These 128 interactions comprise activation ( $n=35)$, repression ( $n=67)$, those with unknown regulatory type $(n=26)$. In general, one may expect the agreement between correlation coefficients and the regulatory types. For instance, the transcriptional activators and their targets are expected to be co-expressed or positively correlated; whereas the repressing gene pairs should be negatively correlated. In our combined co-expression - transcriptional regulatory network; however, these were true for a number of gene pairs in the network but not exclusively, when the transcriptomes from all the tissues available were used to compute the correlation coefficients (Figure 6a).

467 Since we have previously found that the transcriptomic patterns of these flowering genes of interest were mostly grouped together by the tissue types rather than temperature and light conditions, it is possible 
that the types of regulation might be also specific to tissues. To further explore this, we re-calculated the correlation coefficients of transcription levels from each tissue separately.

Overall, our combined co-expression - transcriptional regulatory network consists of 128 interactions that could be divided into two groups: those with known (activation or repression) and unknown type of regulation (Table S7). We sub-classified these interactions based on the agreement between the previously characterized regulatory functions and the concurrence of the correlation coefficients of at least three out of five tissues, using the cutoff of $|\rho| \geq 0.10$ (Figure 6b, see Methods). Out of the 128 interactions, 16 interactions showed consistent positive or negative correlation coefficients of greater than 0.10 in at least three tissues, and thus were considered as the "conserved" interactions throughout the plant tissues. Five of these common interactions were also in agreement with the known regulatory functions. For instance, UBIQUITIN CARRIER PROTEIN 1 (UBC1) and FLOWERING LOCUS C (FLC) demonstrate consistently positive correlation coefficients in whole seedlings, mature pollen grains and roots ( $\rho=0.22,0.66$ and 0.66 , respectively), and indeed, Gu and coworkers have shown that UBC1 activates the transcription of $F L C$ through chromatin modification by monoubiquitination of histone $H 2 B$ in $F L C$ chromatin (Gu et al., 2009). For the 11 common interactions where their types of regulation are not known, this correlation coefficient information can potentially be used to predict the regulatory relationship between the gene pairs. For instance, it has been reported that TARGET OF EAT1 (TOE1) inhibits the activity of CONSTANS (CO), a positive regulator of $F T$ transcription, and hence prevents precocious flowering (Zhang et al., 2015). TOE1 was also identified as a target of SEPALLATA3 (SEP3) by ChIP-seq assay (Kaufmann et al., 2009; Pajoro et al., 2014), but the regulation type between SEP3 and TOE1 was not known to the best of our knowledge. Our co-expression - transcriptional regulatory network showed that the expression of SEP3 was consistently negatively correlated with TOE1 in rosette leaves, mature pollen grains and roots $(\rho=-$ $0.21,-0.20$ and -0.13 , respectively), thus SEP3 might potentially serve as a negative regulator of TOE1. Interestingly, the majority of regulatory interactions in the network (85 out of 128) showed inconsistent positive and negative correlation coefficients among the five tissues, and thus their regulation types could be considered tissue-specific. For instance, the expression of FLC is positively correlated with its target gene SEP3, a gene playing a key role in determining floral organ identity (Pelaz et al., 2000), when the expression from all the available tissues was used to compute Spearman's rank correlation coefficient (red arrow, $\rho=0.58$ ) (Figure 6a). However, this positive correlation would have been the opposite of what had been shown that SEP3 is negatively regulated by FLC, where the TF directly bound to the SEP3 promoter, and the loss of function of FLC in an flc mutant resulted in increased expression of SEP3 (Deng et al., 2011). Looking into our tissue-specific co-expression - transcriptional regulatory networks, we 
observed that the expression of FLC is in fact positively correlated with that of SEP3 only in whole seedlings and pollen grain ( $\rho=0.60$ and 0.13 , respectively), but the two genes did show negative correlations in leaves, shoot apical meristem (SAM) and root ( $\rho=-0.52,-0.24$ and -0.13 , respectively) (Figure $6 \mathrm{c}$ ). This suggests that FLC might repress SEP3 in a tissue-specific manner.

Similarly, it has been showed that FRIGIDA (FRI), which can activate expression of FLC (Choi et al., 2011; Michaels \& Amasino, 1999), is also expressed and functions in several tissues, including leaves, shoot meristem and roots, and the ectopic expression of $F R /$ in those tissues led to delayed flowering. Moreover, the highest increase of $F L C$ expression was observed in the accession expressing $F R /$ specifically in leaves, followed by shoot meristem and roots (Kong et al., 2019). Consistent with this, our result showed strong positive correlation $(\rho=0.60)$ between $F R I$ and $F L C$ in leaves, and more moderate correlations in mature pollen grain and SAM ( $\rho=0.20$ and 0.27 , respectively) (Figure S9). On the other hand, we found that $F R I$ was negatively correlated $(\rho=-0.71$ ) with FLC in root (Figure S9). A possible explanation is that, $F R I$ and $F L C$ might play a different role in root. Indeed, it was revealed that the delay of flowering could be induced by ectopic expression of $F R /$ in the root. Interestingly, the expression of $F L C$ was not affected in this plant, but instead the delayed flowering might be through other activation of FLC-like genes, such as MADS AFFECTING FLOWERING 4 (MAF4) and MAF5 (Kong et al., 2019; Searle et al., 2006).

Other interactions in the network include those with the consistent positive or negative correlation coefficients in all the tissues, but in disagreement with previously known regulatory functions ( 9 out of 128). For instance, P2-like TF SCHLAFMÜTZE (SMZ) that acts as a repressor of flowering and it directly binds downstream of the FT coding region, resulting in a repression of FT (Mathieu et al., 2009). In contrast, we observed that the expression of $S M Z$ was positively correlated with $F T$ in whole seedlings, rosette leaves and mature pollen grain ( $\rho=0.11,0.76$ and 0.40 , respectively). A possible explanation is that the action of SMZ might depend on other proteins or co-repressors since it has been revealed that SMZ required another floral repressor FLOWERING LOCUS M (FLM), to repress FT transcription, as 35S::SMZ plants exhibited markedly reduced $F T$ expression compared with WT, but 35S::SMZ fIm could lead to derepression of $F T$ (Mathieu et al., 2009). It is possible that the TFs regulate their target genes indirectly via other TFs, and thus can be considered as "indirect" interactions. Based on information from FLOR-ID and previous publications, 7 genes were considered as "auto-regulation", 3 out of 7 genes were self-regulated by either repressing or activating their own transcription whereas other 4 genes have been previously reported that they can bind their own genes but their regulatory functions are not known. The rest are the interactions (11 out of 128) whose regulatory functions are not known and cannot be predicted from their correlation coefficients, due to insufficient evidence of consistent coefficients above the cut-off. 


\section{4 | CONCLUSION}

534 The effect of high and low constant temperatures on flowering time control have been well studied to a

535 certain extent in the model plant Arabidopsis thaliana. However, the effect of fluctuating temperature as

536 in the natural daily environment is underappreciated (Burghardt et al., 2016). There are several sets of

537 flowering genes shown to play important regulatory roles in temperature responses, in this study we mainly

538 focused on PHYTOCHROME INTERACTING FACTOR 4 (PIF4) and FLOWERING LOCUS C (FLC), which have

539 antagonistic roles in regulation of flowering time by activating and repressing the floral integrator gene,

540 FLOWERING LOCUS T(FT), respectively (Figure 7).

In this study, we were able to reproduce the results showing that the daily variable temperature

542 (VAR), which mimics a daily fluctuating temperature pattern, as used by Burghardt and colleagues

543 (Burghardt et al., 2016), can promote the floral transition, as compared to constant temperature (CON). In

544 addition, we have demonstrated that the phenomenon is seen in the natural Arabidopsis lines with weak

545 alleles of either FLC or FRI, namely C24, Col-0; as well as their extremely late flowering hybrid, C24xCol-0,

546 which contains the combination of strong alleles of $F L C$ and $F R /$ from Col-0 and C24, respectively (Figure 1c,

547 d). PIF4 plays an important role in acceleration of flowering time at high ambient temperature (Kumar et

548 al., 2012); whereas the prolonged exposure to cold temperature known as vernalization can trigger the

549 floral transition by suppression of FLC (Sheldon et al., 2000; Song et al., 2012) in late-flowering plants that

550 contain both strong alleles of FLC and its activator FRI (Koornneef et al., 1994; Michaels \& Amasino, 1999;

551 Sanda \& Amasino, 1995). Here, we have shown that PIF4 contributed to the early flowering in response to

552 VAR in both natural lines and their late flowering hybrid (Figure 1c, d), and indeed PIF4 transcription level

553 was increased when temperature was high at dusk in VAR, as compared to CON (Figure 2a, b and Figure 7,

554 larger circle). As shown that PIF4 contributes to the induction of flowering under a warm temperature by

555 activating $F T$ transcription (Kumar et al., 2012), here we also observed moderately elevated FT transcription

556 in VAR (Figure 7, larger circle and Figure S4). Hence, we propose that, at least in part, PIF4 and FT play a

557 role in accelerating flowering time under the daily variable temperature condition.

FLC is normally highly functional in the late flowering hybrid C24xCol (Sanda \& Amasino, 1995), and here we have shown that growing the plants in VAR can reduce its transcription levels (Figure 2c, d), especially after 28 DAS. Interestingly, we noticed that the FLC transcription was slightly higher in pif4-101

561 (Figure 2c, d), raising a possibility that PIF4 might also regulate FT expression and flowering time indirectly through the repression of FLC (Figure 7). Here, we demonstrated that the high level of PIF4 might be 
study that found a PIF4 binding site at FLC promoter (Oh et al., 2012). In addition to the PIF4-dependent mechanism, the low transcription level of FLC was observed in VAR, also possibly due to the effect of partial vernalization (Wollenberg \& Amasino, 2012), although neither partial vernalization nor high temperature alone can account for the earlier flowing time in the warm fluctuating temperatures (Burghardt et al., 2016).

Having shown the importance of PIF4 in flowering time acceleration under VAR, we looked further to the evening complex (EC), a well-characterized repressor of PIF4, and its potential regulatory role in this condition. We observed the increase of PIF4 transcription level when temperature was high at dusk (Figure 2a, b), which was coincident with the reduced binding of EC to PIF4 promoter (Box et al., 2015; Ezer et al.,

573 2017; Silva et al., 2020), suggesting a possible function of EC in flowering time acceleration under VAR

574 (Figure 7). However, to our surprise, our flowering time and transcription analysis results also showed that 575 apart from PIF4 and its homologue PIF5, the EC might also repress FT directly or through other regulators 576 to delay flowering (Figure $4 a, b, f$ and Figure 7). This raises a possibility that the role of EC's in shortening 577 the time of flowering in VAR can also be through a PIF-independent pathway. However, this is beyond the 578 scope of this current work.

579 We also demonstrated a conceptual model of gene regulatory mechanisms in controlling flowering 580 time using the combined co-expression - transcriptional regulatory network to explore the relationships 581 between the flowering-time-relating genes of interest, namely PIF4, PIF5, ELF3, and FLC, and their 582 immediate up- and downstream regulatory genes under different temperature conditions. This was 583 achieved by integrating known gene regulatory functions with transcriptional expression levels from 584 publicly available RNA-seq experiments. Based on this approach, we found that the majority of the 585 transcriptional relationships and regulatory types between gene pairs were tissue-specific, suggesting that 586 these flowering genes play unique regulatory roles in different tissues. This network model may help predict 587 the regulatory functions of unknown interactions and identify the set of tissue-specific candidate genes for 588 further exploring their roles in the flowering process. However, it should be noted that the current network 589 model consists of 62 flowering genes, from the total of 306 flowering genes in Arabidopsis, characterized 590 in the Flowering Interactive Database (FLOR-ID) (Bouche et al., 2016). In addition, more RNA-seq 591 experiments from different plant tissues can be appended to further improve the coverage and accuracy 592 of this network model.

593 Overall, we expect that this study will provide improved understanding of how plants perceive and 594 respond to environmental conditions, such as natural fluctuation of daily temperature, in the context of 
bioRxiv preprint doi: https://doi.org/10.1101/2020.10.22.348540; this version posted October 22,2020 . The copyright holder for this preprint (which was not certified by peer review) is the author/funder, who has granted bioRxiv a license to display the preprint in perpetuity. It is made available under aCC-BY-NC-ND 4.0 International license.

flowering time, and provide a platform to breed plants that can adapt to new environments, and may help pave the way to increase crop production in the future.

597

598

599

600

601

602

603

604

605

606

607

608

609

610

611

612

613

614

615

616

617

618

619

620

\section{ACKNOWLEDGEMENTS}

We acknowledge the financial supports from the National Research Council of Thailand (NRCT): NRCT5RSA63015-24 and Thailand Research Fund (TRF): MRG6080235, Faculty of Science, Mahidol University, and the Crown Property Bureau Foundation. JJ was supported by the young researcher scholarship from Faculty of Science, Mahidol University in the first year of her MSc. The authors thank Kawinnat Sue-ob for critical comments on the manuscript.

\section{CONFLICT OF INTEREST}

The authors declare no conflict of interest associated with the work described in this manuscript.

\section{AUTHOR CONTRIBUTIONS}

Jutapak Jenkitkonchai (JJ), VC, PM, WY performed the flowering time and gene expression analyses. JJ and VC analyzed the data. JJ and NS gathered and re-analyzed the RNA-seq experiments. JJ constructed the coexpression - gene regulatory network. VC, Jaehoon Jung (JJH), PW conceived the project. JJ and VC wrote the manuscript. All authors have read and given approval to the final version of the manuscript.

\section{REFERENCES}

Abe, M., Kobayashi, Y., Yamamoto, S., Daimon, Y., Yamaguchi, A., Ikeda, Y., . . Araki, T. (2005). FD, a bZIP protein mediating signals from the floral pathway integrator FT at the shoot apex. Science, 309(5737), 1052-1056. doi:10.1126/science.1115983

Balasubramanian, S., Sureshkumar, S., Lempe, J., \& Weigel, D. (2006). Potent induction of Arabidopsis thaliana flowering by elevated growth temperature. PLoS Genet, 2(7), e106. doi:10.1371/journal.pgen.0020106

Blazquez, M. A., Ahn, J. H., \& Weigel, D. (2003). A thermosensory pathway controlling flowering time in Arabidopsis thaliana. Nat Genet, 33(2), 168-171. doi:10.1038/ng1085 
bioRxiv preprint doi: https://doi.org/10.1101/2020.10.22.348540; this version posted October 22,2020 . The copyright holder for this preprint (which was not certified by peer review) is the author/funder, who has granted bioRxiv a license to display the preprint in perpetuity. It is made available under aCC-BY-NC-ND 4.0 International license.

Jenkitkonchai et al., 2020

621

622

623

624

625

626

627

628

629

630

631

632

633

634

635

636

637

638

639

640

641

642

643

644

645

646

647

648

649

650

651

652

Bouche, F., Lobet, G., Tocquin, P., \& Perilleux, C. (2016). FLOR-ID: an interactive database of flowering-time gene networks in Arabidopsis thaliana. Nucleic Acids Res, 44(D1), D1167-1171. doi:10.1093/nar/gkv1054

Box, M. S., Coustham, V., Dean, C., \& Mylne, J. S. (2011). Protocol: A simple phenol-based method for 96well extraction of high quality RNA from Arabidopsis. Plant Methods, 7, 7. doi:10.1186/1746-48117-7

Box, M. S., Huang, B. E., Domijan, M., Jaeger, K. E., Khattak, A. K., Yoo, S. J., . . Wigge, P. A. (2015). ElF3 controls thermoresponsive growth in Arabidopsis. Curr Biol, 25(2), 194-199. doi:10.1016/j.cub.2014.10.076

Burghardt, L. T., Runcie, D. E., Wilczek, A. M., Cooper, M. D., Roe, J. L., Welch, S. M., \& Schmitt, J. (2016). Fluctuating, warm temperatures decrease the effect of a key floral repressor on flowering time in Arabidopsis thaliana. New Phytol, 210(2), 564-576. doi:10.1111/nph.13799

Capovilla, G., Schmid, M., \& Pose, D. (2015). Control of flowering by ambient temperature. J Exp Bot, 66(1), 59-69. doi:10.1093/jxb/eru416

Choi, K., Kim, J., Hwang, H. J., Kim, S., Park, C., Kim, S. Y., \& Lee, I. (2011). The FRIGIDA complex activates transcription of FLC, a strong flowering repressor in Arabidopsis, by recruiting chromatin modification factors. Plant Cell, 23(1), 289-303. doi:10.1105/tpc.110.075911

Clarke, J. H., \& Dean, C. (1994). Mapping FRI, a locus controlling flowering time and vernalization response in Arabidopsis thaliana. Mol Gen Genet, 242(1), 81-89. doi:10.1007/bf00277351

Cortijo, S., Charoensawan, V., Brestovitsky, A., Buning, R., Ravarani, C., Rhodes, D., . . Wigge, P. A. (2017). Transcriptional Regulation of the Ambient Temperature Response by H2A.Z Nucleosomes and HSF1 Transcription Factors in Arabidopsis. Mol Plant, 10(10), 1258-1273. doi:10.1016/j.molp.2017.08.014

Czechowski, T., Stitt, M., Altmann, T., Udvardi, M. K., \& Scheible, W. R. (2005). Genome-wide identification and testing of superior reference genes for transcript normalization in Arabidopsis. Plant Physiol, 139(1), 5-17. doi:10.1104/pp.105.063743

Deng, W., Ying, H., Helliwell, C. A., Taylor, J. M., Peacock, W. J., \& Dennis, E. S. (2011). FLOWERING LOCUS C (FLC) regulates development pathways throughout the life cycle of Arabidopsis. Proc Natl Acad Sci U S A, 108(16), 6680-6685. doi:10.1073/pnas.1103175108

Dickinson, P. J., Kumar, M., Martinho, C., Yoo, S. J., Lan, H., Artavanis, G., ... Wigge, P. A. (2018). Chloroplast Signaling Gates Thermotolerance in Arabidopsis. Cell Rep, 22(7), 1657-1665. doi:10.1016/j.celrep.2018.01.054 
bioRxiv preprint doi: https://doi.org/10.1101/2020.10.22.348540; this version posted October 22, 2020 . The copyright holder for this preprint (which was not certified by peer review) is the author/funder, who has granted bioRxiv a license to display the preprint in perpetuity. It is made available under aCC-BY-NC-ND 4.0 International license.

Jenkitkonchai et al., 2020

653

654

655

656

657

658

659

660

661

662

663

664

665

666

667

668

669

670

671

672

673

674

675

676

677

678

679

680

681

682

683

Durufle, H., Herve, V., Ranocha, P., Balliau, T., Zivy, M., Chourre, J., . . Dunand, C. (2017). Cell wall modifications of two Arabidopsis thaliana ecotypes, Col and Sha, in response to sub-optimal growth conditions: An integrative study. Plant Sci, 263, 183-193. doi:10.1016/j.plantsci.2017.07.015

Ezer, D., Jung, J. H., Lan, H., Biswas, S., Gregoire, L., Box, M. S., . . Wigge, P. A. (2017). The evening complex coordinates environmental and endogenous signals in Arabidopsis. Nat Plants, 3, 17087. doi:10.1038/nplants.2017.87

Ezer, D., Shepherd, S. J. K., Brestovitsky, A., Dickinson, P., Cortijo, S., Charoensawan, V., . . Wigge, P. A. (2017). The G-Box Transcriptional Regulatory Code in Arabidopsis. Plant Physiol, 175(2), 628-640. doi:10.1104/pp.17.01086

Fernandez, V., Takahashi, Y., Le Gourrierec, J., \& Coupland, G. (2016). Photoperiodic and thermosensory pathways interact through CONSTANS to promote flowering at high temperature under short days. Plant J, 86(5), 426-440. doi:10.1111/tpj.13183

Franklin, K. A., Lee, S. H., Patel, D., Kumar, S. V., Spartz, A. K., Gu, C., . . Gray, W. M. (2011). Phytochromeinteracting factor 4 (PIF4) regulates auxin biosynthesis at high temperature. Proc Natl Acad Sci U S A, 108(50), 20231-20235. doi:10.1073/pnas.1110682108

Fujimori, T., Yamashino, T., Kato, T., \& Mizuno, T. (2004). Circadian-controlled basic/helix-loop-helix factor, PIL6, implicated in light-signal transduction in Arabidopsis thaliana. Plant Cell Physiol, 45(8), 10781086. doi:10.1093/pcp/pch124

Gray, W. M., Ostin, A., Sandberg, G., Romano, C. P., \& Estelle, M. (1998). High temperature promotes auxinmediated hypocotyl elongation in Arabidopsis. Proc Natl Acad Sci U S A, 95(12), 7197-7202. doi:10.1073/pnas.95.12.7197

Gu, X., Jiang, D., Wang, Y., Bachmair, A., \& He, Y. (2009). Repression of the floral transition via histone H2B monoubiquitination. Plant J, 57(3), 522-533. doi:10.1111/j.1365-313X.2008.03709.x

Halliday, K. J., Salter, M. G., Thingnaes, E., \& Whitelam, G. C. (2003). Phytochrome control of flowering is temperature sensitive and correlates with expression of the floral integrator FT. Plant J, 33(5), 875885. doi:10.1046/j.1365-313x.2003.01674.x

Hong, S. M., Bahn, S. C., Lyu, A., Jung, H. S., \& Ahn, J. H. (2010). Identification and testing of superior reference genes for a starting pool of transcript normalization in Arabidopsis. Plant Cell Physiol, 51(10), 1694-1706. doi:10.1093/pcp/pcq128

Huang, H., \& Nusinow, D. A. (2016). Into the Evening: Complex Interactions in the Arabidopsis Circadian Clock. Trends Genet, 32(10), 674-686. doi:10.1016/j.tig.2016.08.002 
bioRxiv preprint doi: https://doi.org/10.1101/2020.10.22.348540; this version posted October 22,2020 . The copyright holder for this preprint (which was not certified by peer review) is the author/funder, who has granted bioRxiv a license to display the preprint in perpetuity. It is made available under aCC-BY-NC-ND 4.0 International license.

Jenkitkonchai et al., 2020

684

685

686

687

688

689

690

691

692

693

694

695

696

697

698

699

700

701

702

703

704

705

706

707

708

709

710

711

712

713

714

715

Hyun, Y., Richter, R., Vincent, C., Martinez-Gallegos, R., Porri, A., \& Coupland, G. (2016). Multi-layered Regulation of SPL15 and Cooperation with SOC1 Integrate Endogenous Flowering Pathways at the Arabidopsis Shoot Meristem. Dev Cell, 37(3), 254-266. doi:10.1016/j.devcel.2016.04.001

Jaeger, K. E., \& Wigge, P. A. J. C. B. (2007). FT protein acts as a long-range signal in Arabidopsis. 17(12), 1050-1054.

Johanson, U., West, J., Lister, C., Michaels, S., Amasino, R., \& Dean, C. (2000). Molecular analysis of FRIGIDA, a major determinant of natural variation in Arabidopsis flowering time. Science, 290(5490), 344347. doi:10.1126/science.290.5490.344

Kaufmann, K., Muino, J. M., Jauregui, R., Airoldi, C. A., Smaczniak, C., Krajewski, P., \& Angenent, G. C. (2009). Target genes of the MADS transcription factor SEPALLATA3: integration of developmental and hormonal pathways in the Arabidopsis flower. PLoS Biol, 7(4), e1000090. doi:10.1371/journal.pbio.1000090

Koini, M. A., Alvey, L., Allen, T., Tilley, C. A., Harberd, N. P., Whitelam, G. C., \& Franklin, K. A. (2009). High temperature-mediated adaptations in plant architecture require the bHLH transcription factor PIF4. Curr Biol, 19(5), 408-413. doi:10.1016/j.cub.2009.01.046

Kong, X., Luo, L., Zhao, J., Chen, Q., Chang, G., Huang, J., . . Hu, X. (2019). Expression of FRIGIDA in root inhibits flowering in Arabidopsis thaliana. J Exp Bot, 70(19), 5101-5114. doi:10.1093/jxb/erz287

Koornneef, M., Blankestijn-de Vries, H., Hanhart, C., Soppe, W., \& Peeters, T. J. T. P. J. (1994). The phenotype of some late-flowering mutants is enhanced by a locus on chromosome 5 that is not effective in the Landsberg erecta wild-type. 6(6), 911-919.

Kumar, S. V., Lucyshyn, D., Jaeger, K. E., Alos, E., Alvey, E., Harberd, N. P., \& Wigge, P. A. (2012). Transcription factor PIF4 controls the thermosensory activation of flowering. Nature, 484(7393), 242-245. doi:10.1038/nature10928

Kunihiro, A., Yamashino, T., Nakamichi, N., Niwa, Y., Nakanishi, H., \& Mizuno, T. (2011). Phytochromeinteracting factor 4 and 5 (PIF4 and PIF5) activate the homeobox ATHB2 and auxin-inducible IAA29 genes in the coincidence mechanism underlying photoperiodic control of plant growth of Arabidopsis thaliana. Plant Cell Physiol, 52(8), 1315-1329. doi:10.1093/pcp/pcr076

Lee, I., Bleecker, A., \& Amasino, R. (1993). Analysis of naturally occurring late flowering in Arabidopsis thaliana. Mol Gen Genet, 237(1-2), 171-176. doi:10.1007/BF00282798

Lorrain, S., Allen, T., Duek, P. D., Whitelam, G. C., \& Fankhauser, C. (2008). Phytochrome-mediated inhibition of shade avoidance involves degradation of growth-promoting bHLH transcription factors. Plant J, 53(2), 312-323. doi:10.1111/j.1365-313X.2007.03341.x 
bioRxiv preprint doi: https://doi.org/10.1101/2020.10.22.348540; this version posted October 22,2020 . The copyright holder for this preprint (which was not certified by peer review) is the author/funder, who has granted bioRxiv a license to display the preprint in perpetuity. It is made available under aCC-BY-NC-ND 4.0 International license.

Jenkitkonchai et al., 2020

Macknight, R., Duroux, M., Laurie, R., Dijkwel, P., Simpson, G., \& Dean, C. (2002). Functional significance of the alternative transcript processing of the Arabidopsis floral promoter FCA. Plant Cell, 14(4), 877888. doi:10.1105/tpc.010456

Martins, S., Montiel-Jorda, A., Cayrel, A., Huguet, S., Roux, C. P., Ljung, K., \& Vert, G. (2017). Brassinosteroid signaling-dependent root responses to prolonged elevated ambient temperature. Nat Commun, 8(1), 309. doi:10.1038/s41467-017-00355-4

Mathieu, J., Yant, L. J., Murdter, F., Kuttner, F., \& Schmid, M. (2009). Repression of flowering by the miR172 target SMZ. PLoS Biol, 7(7), e1000148. doi:10.1371/journal.pbio.1000148

Michaels, S. D., \& Amasino, R. M. (1999). FLOWERING LOCUS C encodes a novel MADS domain protein that acts as a repressor of flowering. Plant Cell, 11(5), 949-956. doi:10.1105/tpc.11.5.949

Mizuno, T., Nomoto, Y., Oka, H., Kitayama, M., Takeuchi, A., Tsubouchi, M., \& Yamashino, T. (2014). Ambient temperature signal feeds into the circadian clock transcriptional circuitry through the EC night-time repressor in Arabidopsis thaliana. Plant Cell Physiol, 55(5), 958-976. doi:10.1093/pcp/pcu030

Niwa, Y., Yamashino, T., \& Mizuno, T. (2009). The circadian clock regulates the photoperiodic response of hypocotyl elongation through a coincidence mechanism in Arabidopsis thaliana. Plant Cell Physiol, 50(4), 838-854. doi:10.1093/pcp/pcp028

Nomoto, Y., Kubozono, S., Miyachi, M., Yamashino, T., Nakamichi, N., \& Mizuno, T. (2013). Circadian clock and PIF4-mediated external coincidence mechanism coordinately integrates both of the cues from seasonal changes in photoperiod and temperature to regulate plant growth in Arabidopsis thaliana. Plant Signal Behav, 8(2), e22863. doi:10.4161/psb.22863

Nozue, K., Covington, M. F., Duek, P. D., Lorrain, S., Fankhauser, C., Harmer, S. L., \& Maloof, J. N. (2007). Rhythmic growth explained by coincidence between internal and external cues. Nature, 448(7151), 358-361. doi:10.1038/nature05946

Nozue, K., Tat, A. V., Kumar Devisetty, U., Robinson, M., Mumbach, M. R., Ichihashi, Y., . . Maloof, J. N. (2015). Shade avoidance components and pathways in adult plants revealed by phenotypic profiling. PLoS Genet, 11(4), e1004953. doi:10.1371/journal.pgen.1004953

Nusinow, D. A., Helfer, A., Hamilton, E. E., King, J. J., Imaizumi, T., Schultz, T. F., . . Kay, S. A. (2011). The ELF4-ELF3-LUX complex links the circadian clock to diurnal control of hypocotyl growth. Nature, 475(7356), 398-402. doi:10.1038/nature10182

Oh, E., Zhu, J. Y., \& Wang, Z. Y. (2012). Interaction between BZR1 and PIF4 integrates brassinosteroid and environmental responses. Nat Cell Biol, 14(8), 802-809. doi:10.1038/ncb2545 
bioRxiv preprint doi: https://doi.org/10.1101/2020.10.22.348540; this version posted October 22,2020 . The copyright holder for this preprint (which was not certified by peer review) is the author/funder, who has granted bioRxiv a license to display the preprint in perpetuity. It is made available under aCC-BY-NC-ND 4.0 International license.

Jenkitkonchai et al., 2020

Pajoro, A., Madrigal, P., Muino, J. M., Matus, J. T., Jin, J., Mecchia, M. A., ... Kaufmann, K. (2014). Dynamics of chromatin accessibility and gene regulation by MADS-domain transcription factors in flower development. Genome Biol, 15(3), R41. doi:10.1186/gb-2014-15-3-r41

Pajoro, A., Severing, E., Angenent, G. C., \& Immink, R. G. H. (2017). Histone H3 lysine 36 methylation affects temperature-induced alternative splicing and flowering in plants. Genome Biol, 18(1), 102. doi:10.1186/s13059-017-1235-x

Pelaz, S., Ditta, G. S., Baumann, E., Wisman, E., \& Yanofsky, M. F. (2000). B and C floral organ identity functions require SEPALLATA MADS-box genes. Nature, 405(6783), 200-203. doi:10.1038/35012103

Pouteau, S., \& Albertini, C. (2009). The significance of bolting and floral transitions as indicators of reproductive phase change in Arabidopsis. J Exp Bot, 60(12), 3367-3377. doi:10.1093/jxb/erp173

Rahmati Ishka, M., Brown, E., Weigand, C., Tillett, R. L., Schlauch, K. A., Miller, G., \& Harper, J. F. (2018). A comparison of heat-stress transcriptome changes between wild-type Arabidopsis pollen and a heat-sensitive mutant harboring a knockout of cyclic nucleotide-gated cation channel 16 (cngc16). BMC Genomics, 19(1), 549. doi:10.1186/s12864-018-4930-4

R Core Team (2019). R: A language and environment for statistical computing. R Foundation for Statistical Computing, Vienna, Austria. URL https://www.R-project.org/.

Rivero, L., Scholl, R., Holomuzki, N., Crist, D., Grotewold, E., \& Brkljacic, J. (2014). Handling Arabidopsis plants: growth, preservation of seeds, transformation, and genetic crosses. Methods Mol Biol, 1062, 3-25. doi:10.1007/978-1-62703-580-4_1

Salome, P. A., \& McClung, C. R. (2004). The Arabidopsis thaliana clock. J Biol Rhythms, 19(5), 425-435. doi:10.1177/0748730404268112

Samach, A., \& Wigge, P. A. (2005). Ambient temperature perception in plants. Curr Opin Plant Biol, 8(5), 483-486. doi:10.1016/j.pbi.2005.07.011

Sanda, S. L., \& Amasino, R. M. J. W. W. (1995). Genetic and physiological analysis of flowering time in the C24 line of Arabidopsis thaliana. 2, 2-8.

Searle, I., He, Y., Turck, F., Vincent, C., Fornara, F., Krober, S., . . Coupland, G. (2006). The transcription factor FLC confers a flowering response to vernalization by repressing meristem competence and systemic signaling in Arabidopsis. Genes Dev, 20(7), 898-912. doi:10.1101/gad.373506

Shannon, P., Markiel, A., Ozier, O., Baliga, N. S., Wang, J. T., Ramage, D., .. Ideker, T. (2003). Cytoscape: a software environment for integrated models of biomolecular interaction networks. Genome Res, 13(11), 2498-2504. doi:10.1101/gr.1239303 
bioRxiv preprint doi: https://doi.org/10.1101/2020.10.22.348540; this version posted October 22, 2020 . The copyright holder for this preprint (which was not certified by peer review) is the author/funder, who has granted bioRxiv a license to display the preprint in perpetuity. It is made available under aCC-BY-NC-ND 4.0 International license.

Jenkitkonchai et al., 2020

780

781

782

783

784

785

786

787

788

789

790

791

792

793

794

795

796

797

798

799

800

801

802

803

804

805

806

807

808

809

810

811

Sheldon, C. C., Rouse, D. T., Finnegan, E. J., Peacock, W. J., \& Dennis, E. S. (2000). The molecular basis of vernalization: the central role of FLOWERING LOCUS C (FLC). Proc Natl Acad Sci U S A, 97(7), 37533758. doi:10.1073/pnas.060023597

Shindo, C., Aranzana, M. J., Lister, C., Baxter, C., Nicholls, C., Nordborg, M., \& Dean, C. (2005). Role of FRIGIDA and FLOWERING LOCUS $\mathrm{C}$ in determining variation in flowering time of Arabidopsis. Plant Physiol, 138(2), 1163-1173. doi:10.1104/pp.105.061309

Silva, C. S., Nayak, A., Lai, X., Hutin, S., Hugouvieux, V., Jung, J. H., . . Zubieta, C. (2020). Molecular mechanisms of Evening Complex activity in Arabidopsis. Proc Natl Acad Sci U S A, 117(12), 69016909. doi:10.1073/pnas.1920972117

Song, J., Angel, A., Howard, M., \& Dean, C. (2012). Vernalization - a cold-induced epigenetic switch. J Cell Sci, 125(Pt 16), 3723-3731. doi:10.1242/jcs.084764

Sun, J., Qi, L., Li, Y., Chu, J., \& Li, C. (2012). PIF4-mediated activation of YUCCA8 expression integrates temperature into the auxin pathway in regulating arabidopsis hypocotyl growth. PLoS Genet, 8(3), e1002594. doi:10.1371/journal.pgen.1002594

Tasset, C., Singh Yadav, A., Sureshkumar, S., Singh, R., van der Woude, L., Nekrasov, M., . . . Balasubramanian, S. (2018). POWERDRESS-mediated histone deacetylation is essential for thermomorphogenesis in Arabidopsis thaliana. PLoS Genet, 14(3), e1007280. doi:10.1371/journal.pgen.1007280

Thines, B. C., Youn, Y., Duarte, M. I., \& Harmon, F. G. (2014). The time of day effects of warm temperature on flowering time involve PIF4 and PIF5. J Exp Bot, 65(4), 1141-1151. doi:10.1093/jxb/ert487

Wigge, P. A., Kim, M. C., Jaeger, K. E., Busch, W., Schmid, M., Lohmann, J. U., \& Weigel, D. (2005). Integration of spatial and temporal information during floral induction in Arabidopsis. Science, 309(5737), 1056-1059. doi:10.1126/science.1114358

Wilczek, A. M., Roe, J. L., Knapp, M. C., Cooper, M. D., Lopez-Gallego, C., Martin, L. J., . . Schmitt, J. (2009). Effects of genetic perturbation on seasonal life history plasticity. Science, 323(5916), 930-934. doi:10.1126/science.1165826

Wollenberg, A. C., \& Amasino, R. M. (2012). Natural variation in the temperature range permissive for vernalization in accessions of Arabidopsis thaliana. Plant Cell Environ, 35(12), 2181-2191. doi:10.1111/j.1365-3040.2012.02548.x

Zhang, B., Wang, L., Zeng, L., Zhang, C., \& Ma, H. (2015). Arabidopsis TOE proteins convey a photoperiodic signal to antagonize CONSTANS and regulate flowering time. Genes Dev, 29(9), 975-987. doi:10.1101/gad.251520.114 
bioRxiv preprint doi: https://doi.org/10.1101/2020.10.22.348540; this version posted October 22,2020 . The copyright holder for this preprint (which was not certified by peer review) is the author/funder, who has granted bioRxiv a license to display the preprint in perpetuity. It is made available under aCC-BY-NC-ND 4.0 International license.

Jenkitkonchai et al., 2020

812 Zhu, W., Ausin, I., Seleznev, A., Mendez-Vigo, B., Pico, F. X., Sureshkumar, S., .. Balasubramanian, S. (2015). Natural Variation Identifies ICARUS1, a Universal Gene Required for Cell Proliferation and Growth at High Temperatures in Arabidopsis thaliana. PLoS Genet, 11(5), e1005085. doi:10.1371/journal.pgen.1005085 


\section{FIGURE LEGENDS}

818

FIGURE 1 PHYTOCHROME INTERACTING FACTOR 4 (PIF4) contributes to accelerated flowering time in response to daily variable temperature. (a) The profiles of constant (CON) and variable (VAR) temperature conditions under the short-day (SD) photoperiod used in this study (adapted from Burghardt et al., 2016). $\operatorname{CON}\left(22^{\circ} \mathrm{C}\right)$ is shown as a dashed blue line, and VAR (also $22^{\circ} \mathrm{C}$ on average) is shown as a solid green line. The rectangles below the graph describe the light condition of the short-day cycle ( $8 \mathrm{~h}$ light/16 $\mathrm{h}$ dark), where the lights were on (yellow) and off (black); ZT, Zeitgeber time. (b) C24xCol-0 grown in CON (left) and VAR (right) conditions at 115 days after sowing (DAS). Red arrow indicates inflorescence (c) Boxplots showing the total number of days to flowering of the plants grown under the CON (blue) and VAR conditions (green). (d) Boxplots showing the total number of rosette leaves at flowering days. Solid lines inside the boxes represent medians. Each dot represents the result of each plant. There were 6 and 12 plants per line per condition. Statistical test between the two groups was computed by Wilcoxon rank sum test, $p \leq 0.0001$ $(* * * *), p \leq 0.001\left(^{* * *}\right), p \leq 0.01(* *), p \leq 0.05(*)$ and $p>0.05$ (ns).

FIGURE 2 Dynamic changes of transcript levels of PIF4 and FLC under the constant and variable temperature conditions. Boxplots showing the relative expressions of flowering related-genes of Col-0, C24, C24xCol and pif4-101 of individual plants as individual white dots, normalized to the average of transcription level of Col-0 CON ZTO (control). (a) PIF4 at 10 DAS; (b) PIF4 at 28 DAS (the primers used were PIF4_6981/PIF4_6982); (c) FLC at 10 DAS; (d) FLC at 28 DAS. Black lines inside the boxes represent medians.

FIGURE 3 The late flowering of C24xCol can be mitigated by overexpression of PIF4 in C24×35S::PIF4 (a) Boxplots showing the total number of days to flowering of the plants grown under the CON (blue) and VAR (green) conditions. (b) Boxplots showing the total number of rosette leaves at the flowering days. Solid lines inside the boxes represent medians. Data points outside the boxes represent outliers. Each dot represents data from each plant. There were between 18 to 27 plants per line per condition. Statistical test between the two groups was computed by Wilcoxon rank sum test, $p \leq 0.0001(* * *), p \leq 0.001(* * *), p \leq 0.01(* *)$, $p \leq 0.05\left(^{*}\right)$ and $p>0.05$ (ns). (c-e) Boxplots showing relative expressions of flowering related-genes namely PIF4 (the primers used were PIF4_6581/PIF4_6582), FLC and FT (the primers used were FT_7380/FT_7381) of plants grown under constant $22^{\circ} \mathrm{C}$ at 10-day after sowing (10 DAS) from 3 individual plants, normalized to the average transcription level of Col-0 ZTO (control). 
bioRxiv preprint doi: https://doi.org/10.1101/2020.10.22.348540; this version posted October 22,2020 . The copyright holder for this preprint (which was not certified by peer review) is the author/funder, who has granted bioRxiv a license to display the preprint in perpetuity. It is made available under aCC-BY-NC-ND 4.0 International license.

Jenkitkonchai et al., 2020

FIGURE 4 Role of evening complex (EC) in regulating flowering time through PIF4 and PIF5 and the FT pathway. (a) Boxplots showing the total number of days to flowering of the plants grown under the constant temperature condition $\left(22 \pm 1^{\circ} \mathrm{C}\right)$. (b) Boxplots showing the total number of rosette leaves at flowering days. Solid lines inside the boxes represent medians. Data points outside the boxes represent outliers. Each dot represents data from each plant. There were 9 plants per line. Statistical test between the two groups was computed by Wilcoxon rank sum test, $p \leq 0.0001\left(^{* * * *}\right), p \leq 0.001(* * *), p \leq 0.01(* *), p \leq 0.05\left({ }^{*}\right)$ and $p>$

8550.05 (ns). (c-f) Boxplots showing the relative expressions of flowering genes namely PIF4 856 (PIF4_6981/PIF4_6982 primers), PIF5, FLC and FT (FT_7380/FT_7381 primers) of plants at 28 DAS from 3 857 individual plants, normalized to the average of transcription level of Col-0 ZTO (control).

859 FIGURE 5 Conserved and tissue-specific transcriptional patterns of flowering genes of interest, in response 860 to temperature changes. Heatmap showing the transcriptional patterns of 62 flowering-time-relating 861 genes, namely PIF4, PIF5, ELF3, FLC and their immediate up- and downstream genes from (a) all five tissues, 862 (b) shoot apical meristem, SAM (from the studies by Pajoro et al., 2017) and (c) root (from the Martins et 863 al., 2017 study) of Arabidopsis thaliana ecotype Col-0 grown under different temperature and light 864 conditions. Z-scores of TPM values were calculated across the samples. Yellow indicates relative up865 regulation and blue indicates down-regulation.

867 FIGURE 6 A co-expression - transcriptional regulatory network reveals the tissue-specific interactions 868 between flowering genes. (a) Overview of the co-expression - transcriptional regulatory network of 62 flowering related-genes based on expression profiles from all available tissues. Node colors represent the flowering genes of interest, namely PIF4, PIF5, ELF3, FLC (grey) and their immediate up- and downstream

871 flowering genes (yellow). Edge colors represent the correlation coefficients: positive (red) and negative 872 correlation (blue), using Spearman's correlation coefficient method. Lower correlation values are shown as 873 paler-color edges and higher correlation values as darker-color edges. Solid/dashed black lines represent 874 auto-regulation. (b) Pie chart showing the proportions of interaction types of gene pairs in the combined 875 network. (c) Sub-network modules showing the expression correlations computed from individual tissues 876 namely, whole seedling, mature pollen grain, rosette leaves, shoot apical meristem (SAM), and root. Black 877 arrows indicate the gene pair where their co-expression coefficients vary by tissues. 
bioRxiv preprint doi: https://doi.org/10.1101/2020.10.22.348540; this version posted October 22,2020 . The copyright holder for this preprint (which was not certified by peer review) is the author/funder, who has granted bioRxiv a license to display the preprint in perpetuity. It is made available under aCC-BY-NC-ND 4.0 International license.

879 FIGURE 7 Interactions and dynamics of the flowering genes FT, PIF4, EC, FLC and FRI, and their regulatory

880 roles in flowering time determination, in response to the daily variable temperature. The working model

881 shows the interactions of the flowering related-genes/proteins in flowering time regulation under constant

882 (CON) and variable (VAR) temperature conditions in the short-day (SD) photoperiod. Circles represent the

883 genes or proteins and the sizes of circles represents the abundance (transcription levels) of genes. Solid

884 lines with arrow and block heads indicate activation and repression, respectively.

885

886 


\section{SUPPORTING INFORMATION}

889

890

891

892

893

894

895

896

897

898

899

900

901

902

903

\section{Supplementary Tables}

905 Table S1 Oligonucleotide primers used in this study

906 Table S2 A list of 62 flowering-related genes including PIF4, PIF5, ELF3, FLC and their up- and downstream

907 genes

908 Table S3 RNA-seq datasets and the experimental conditions used in this study

909 Table S4 Normalized TPM values of 62 flowering-related genes from 152 RNA-seq datasets

910 Table S5 A list of flowering-related genes in each clusters for shoot apical meristem (SAM) tissue

911 Table S6 A list of flowering-related genes in each clusters for root tissue

912 Table S7 The summary of the correlation coefficients in each tissues and regulatory functions of 128

913 interactions

914

915

Additional File

916

917

The combined co-expression - transcriptional regulatory networks of all tissues, whole seedlings, rosette leaves, shoot apical meristem (SAM), root and mature pollen grain in Cytoscape session file (.cys) format. 
bioRxiv preprint doi: https://doi.org/10.1101/2020.10.22.348540; this version posted October 22, 2020. The copyright holder for this preprint (which was not certified by peer review) is the author/funder, who has granted bioRxiv a license to display the preprint in perpetuity. It is made available under aCC-BY-NC-ND 4.0 International license.

\section{FIGURE 1}

(a)

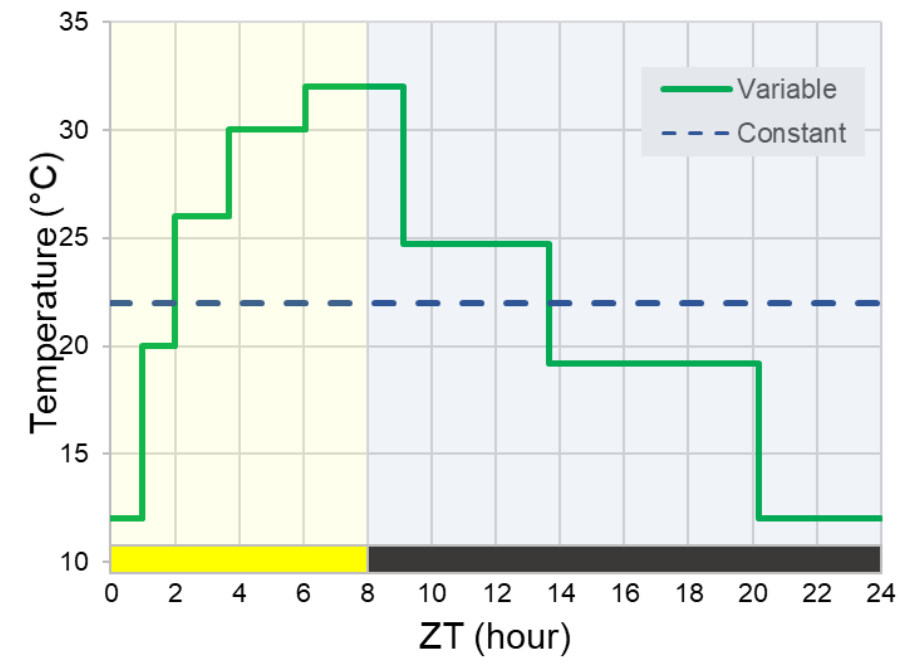

(c)

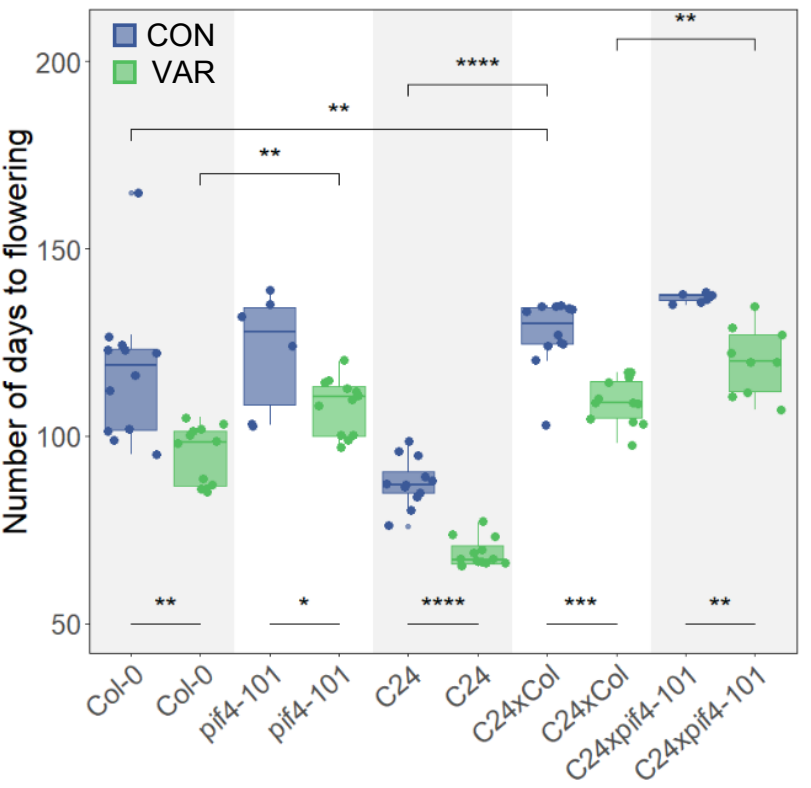

(b)

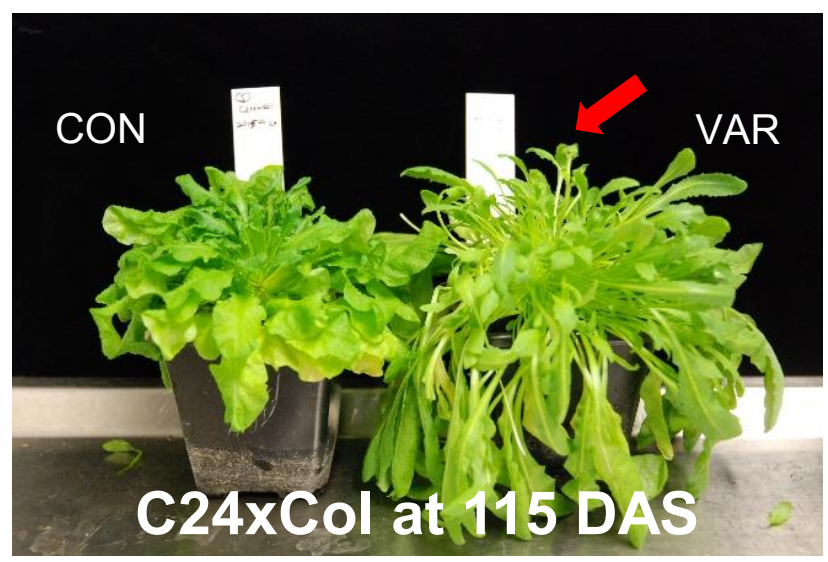

(d)

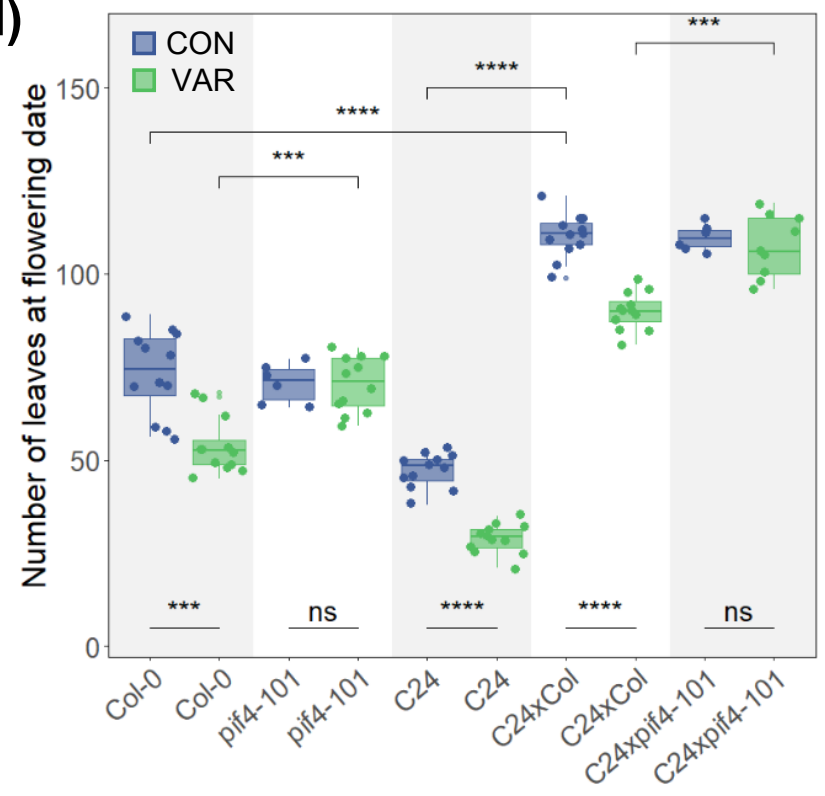


bioRxiv preprint doi: https://doi.org/10.1101/2020.10.22.348540; this version posted October 22, 2020. The copyright holder for this preprint (which was not certified by peer review) is the author/funder, who has granted bioRxiv a license to display the preprint in perpetuity. It is made available under aCC-BY-NC-ND 4.0 International license.

\section{FIGURE 2}

(a)

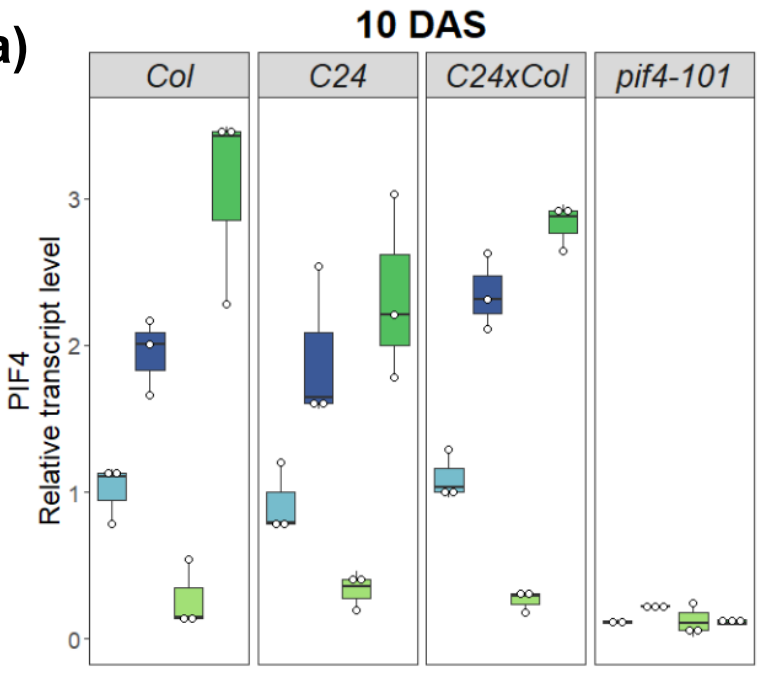

(c)

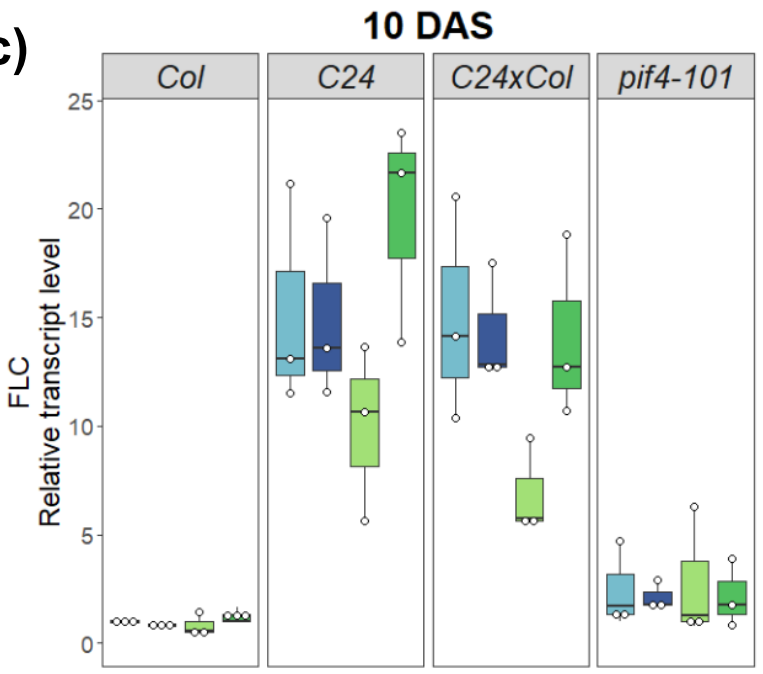

(b) 皁 ZTO CON ZT8 CON ZTO VAR ZT8 VAR
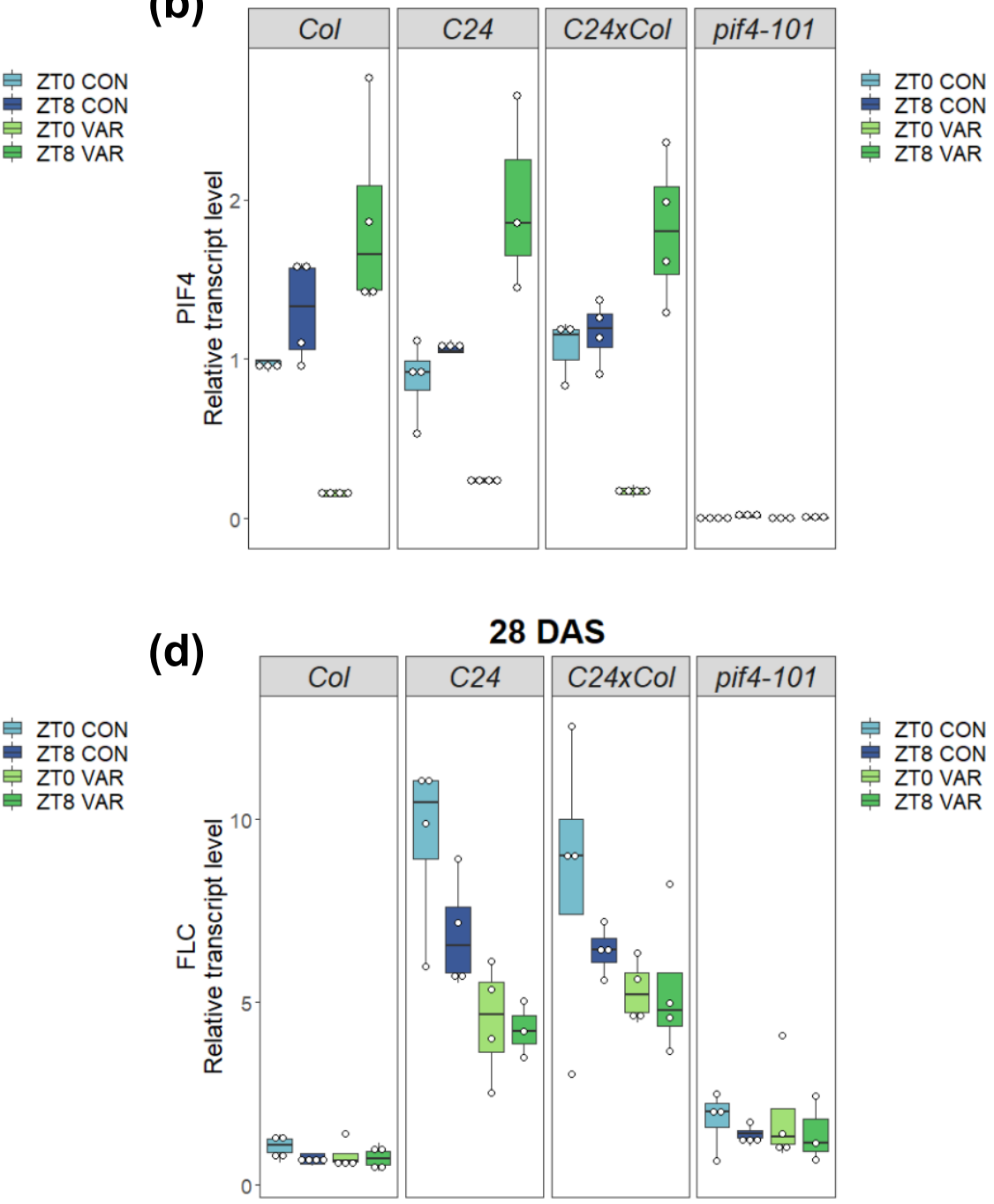

부 ZTO CON

ZT8 CON

追 ZTO VAR

皋 ZT8 VAR 
bioRxiv preprint doi: https://doi.org/10.1101/2020.10.22.348540; this version posted October 22, 2020. The copyright holder for this preprint (which was not certified by peer review) is the author/funder, who has granted bioRxiv a license to display the preprint in perpetuity. It is made available under aCC-BY-NC-ND 4.0 International license.

\section{FIGURE 3}

(a)

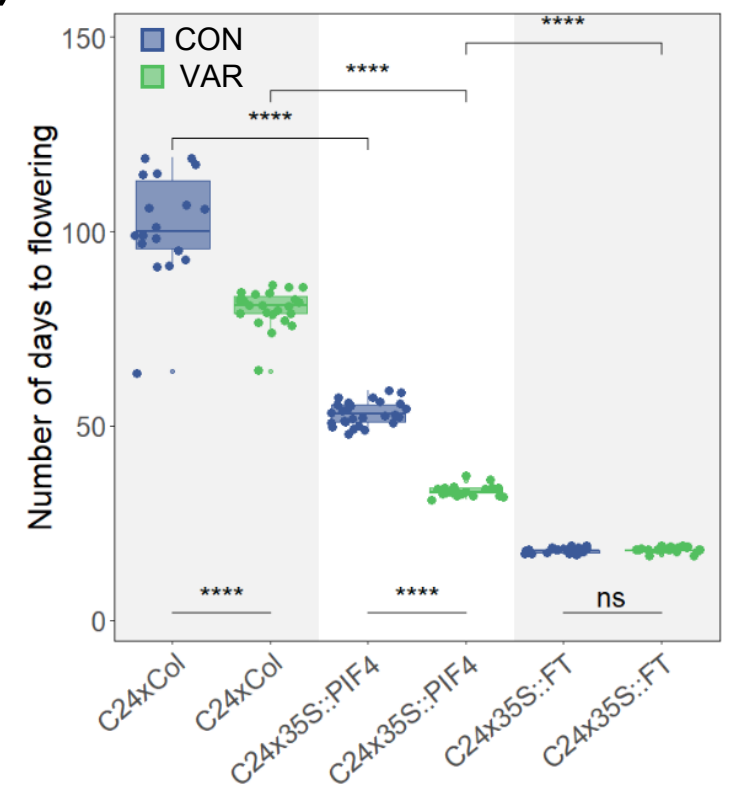

(c)

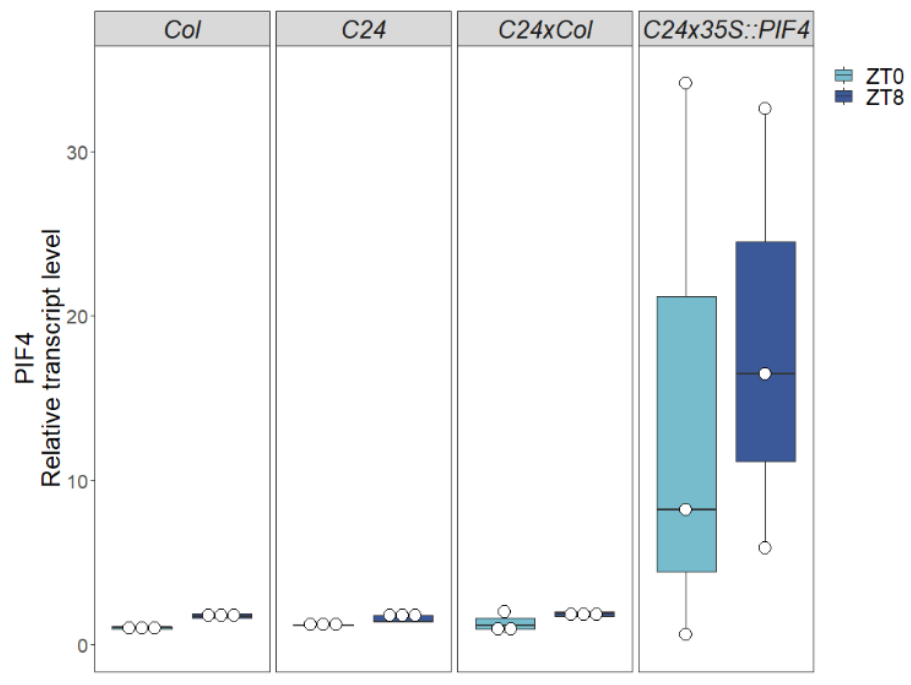

(b)

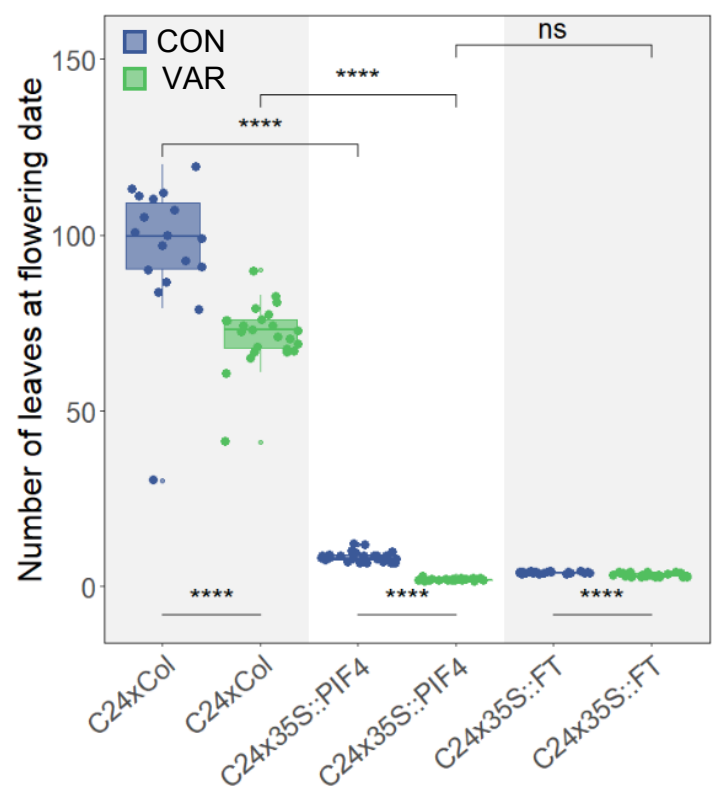

(d)

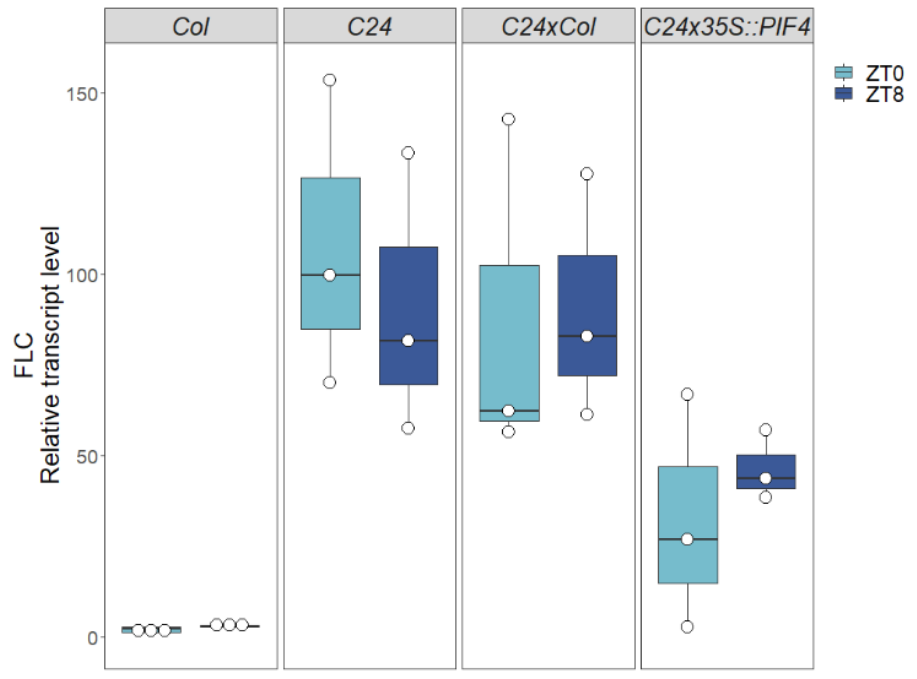

(e)

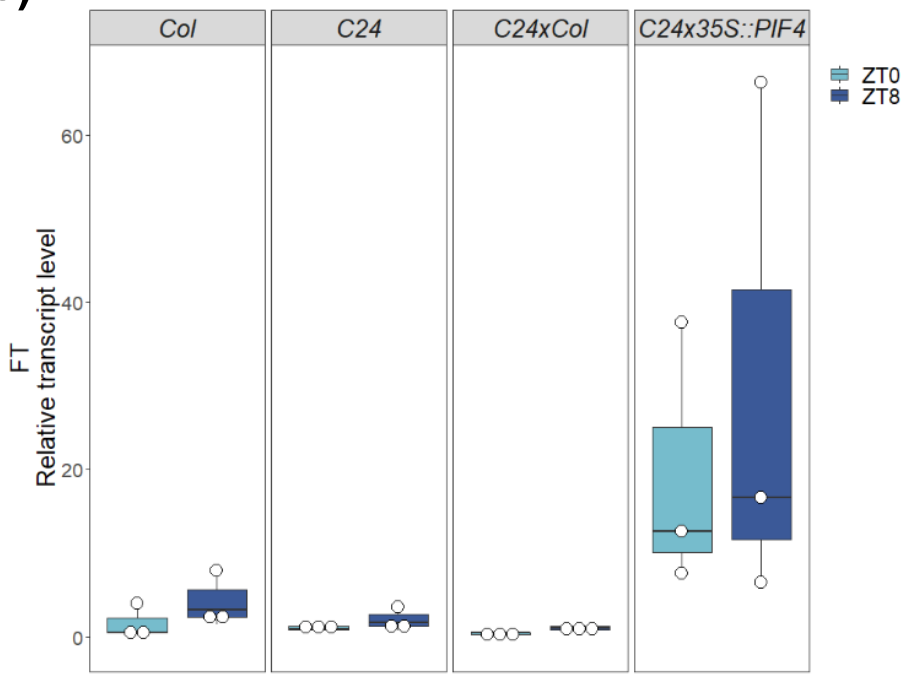


bioRxiv preprint doi: https://doi.org/10.1101/2020.10.22.348540; this version posted October 22, 2020. The copyright holder for this preprint (which was not certified by peer review) is the author/funder, who has granted bioRxiv a license to display the preprint in perpetuity. It is made available under aCC-BY-NC-ND 4.0 International license.

\section{FIGURE 4}

(a)

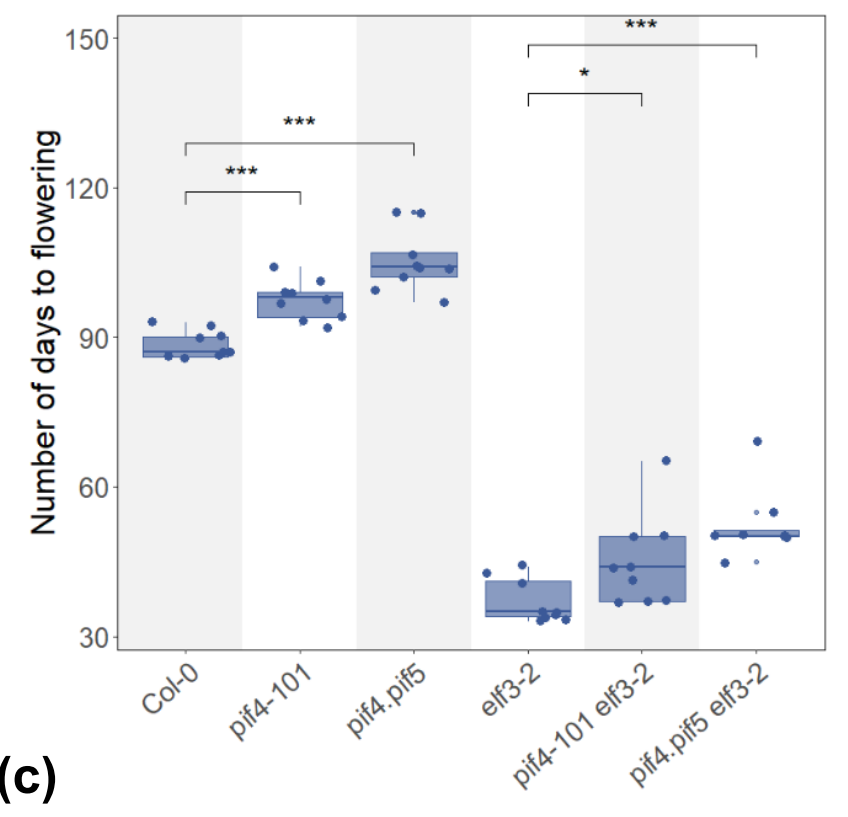

(b)

(d)

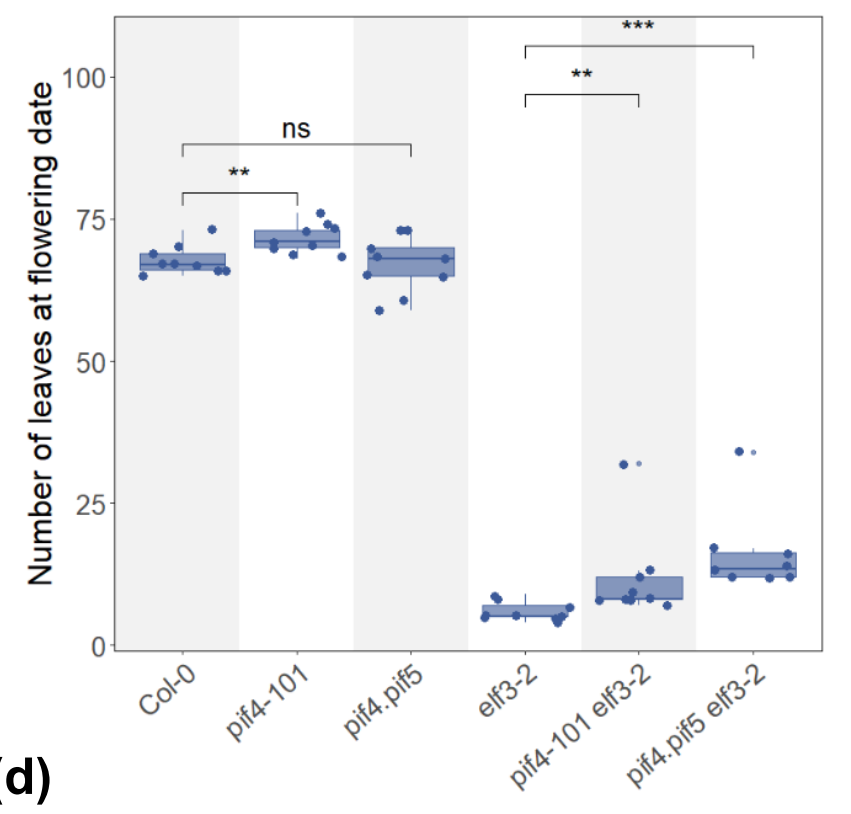

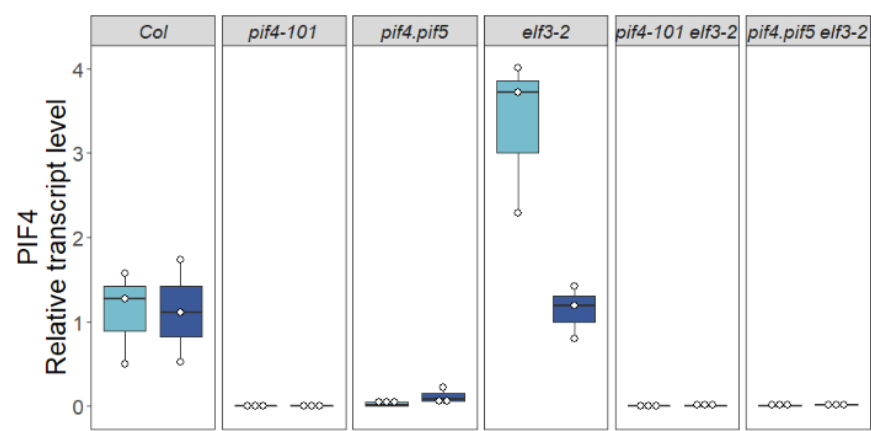

(e)

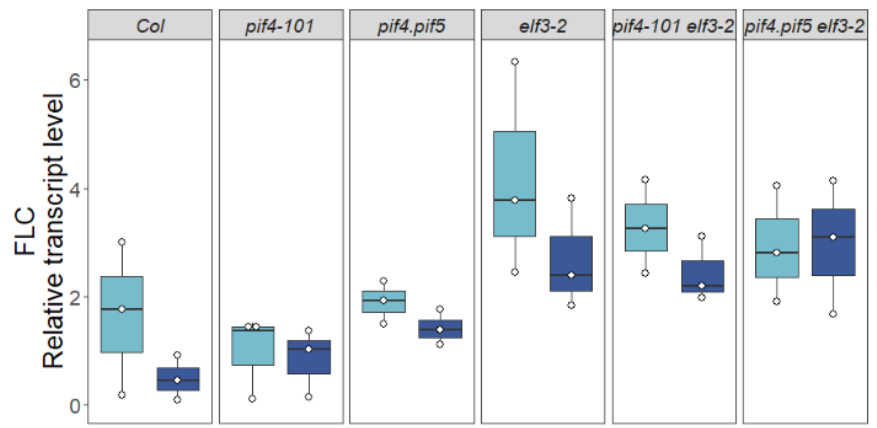

自 ZTO

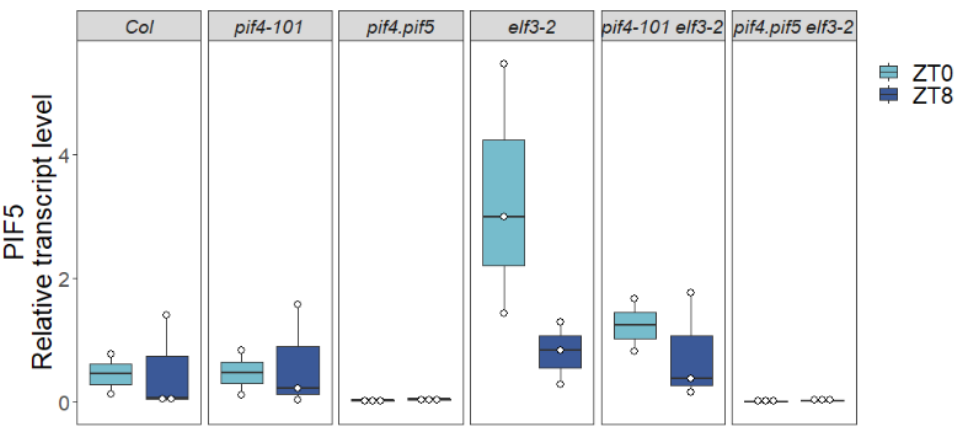

(f)

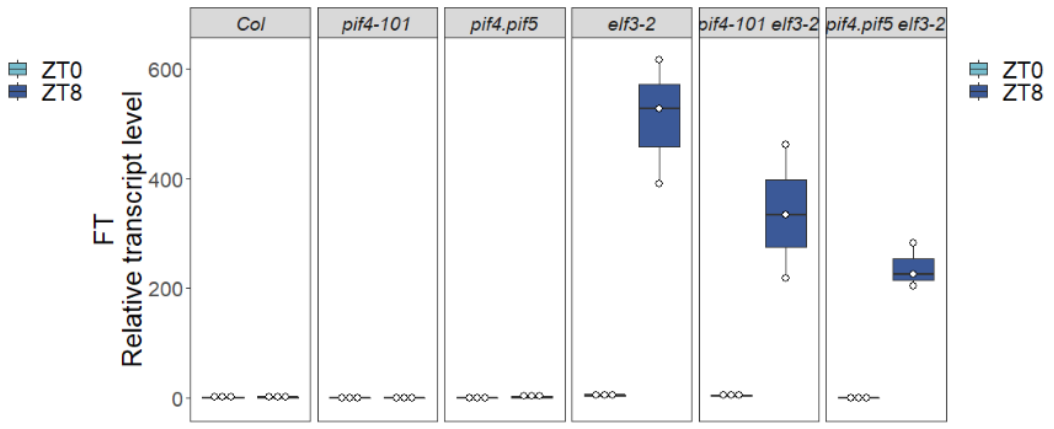


bioRxiv preprint doi: https://doi.org/10.1101/2020.10.22.348540; this version posted October 22, 2020. The copyright holder for this

preprint (which was not certified by peer review) is the author/funder, who has granted bioRxiv a license to display the preprint in perpetuity. It is made available under aCC-BY-NC-ND 4.0 International license.

\section{FIGURE 5}

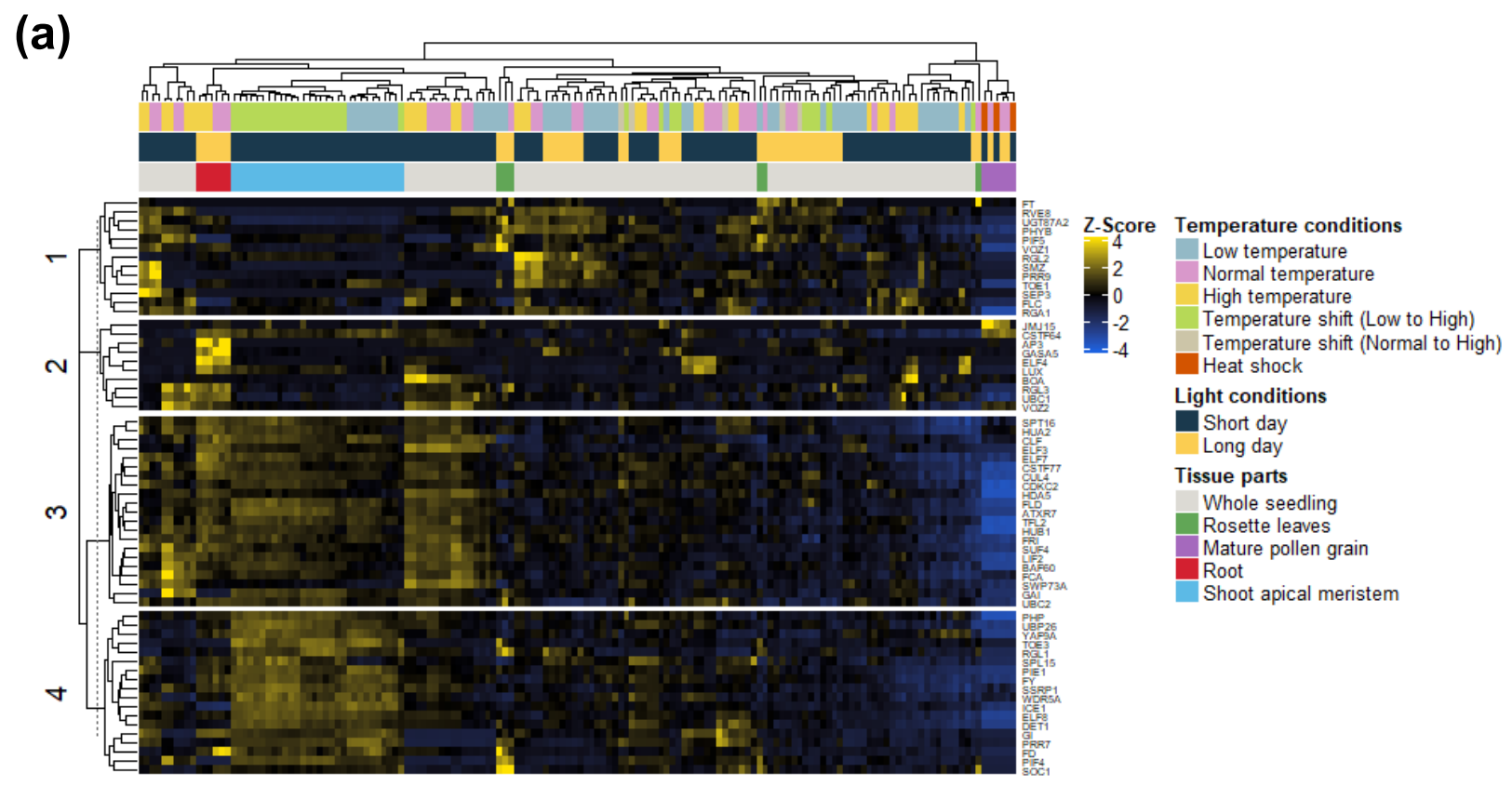

(b)

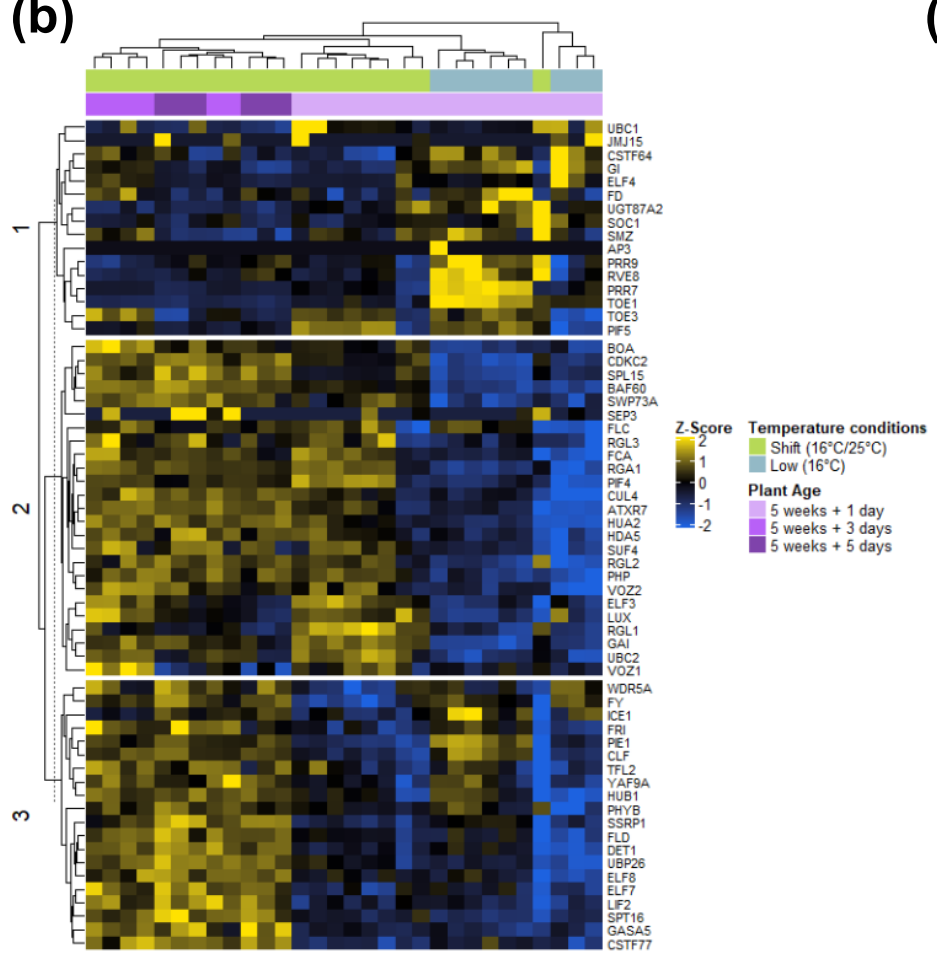

(c)

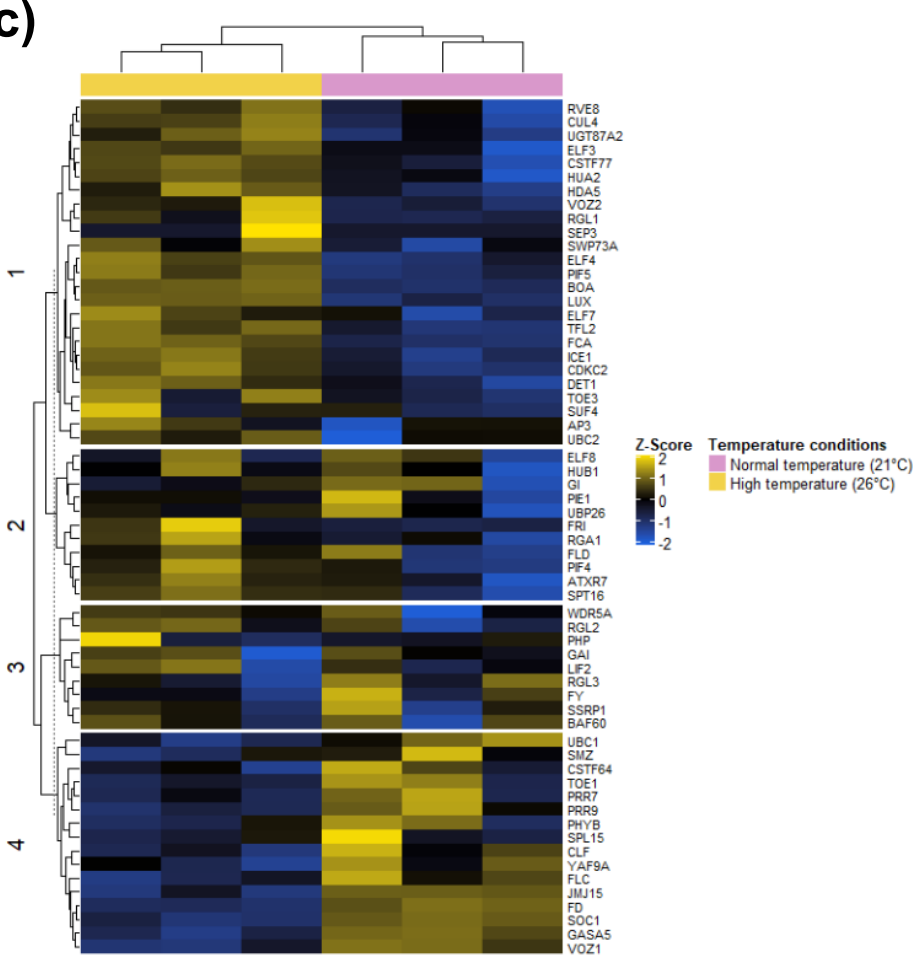


bioRxiv preprint doi: https://doi.org/10.1101/2020.10.22.348540; this version posted October 22, 2020. The copyright holder for this preprint (which was not certified by peer review) is the author/funder, who has granted bioRxiv a license to display the preprint in perpetuity. It is made available under aCC-BY-NC-ND 4.0 International license.

\section{FIGURE 6}

(a)

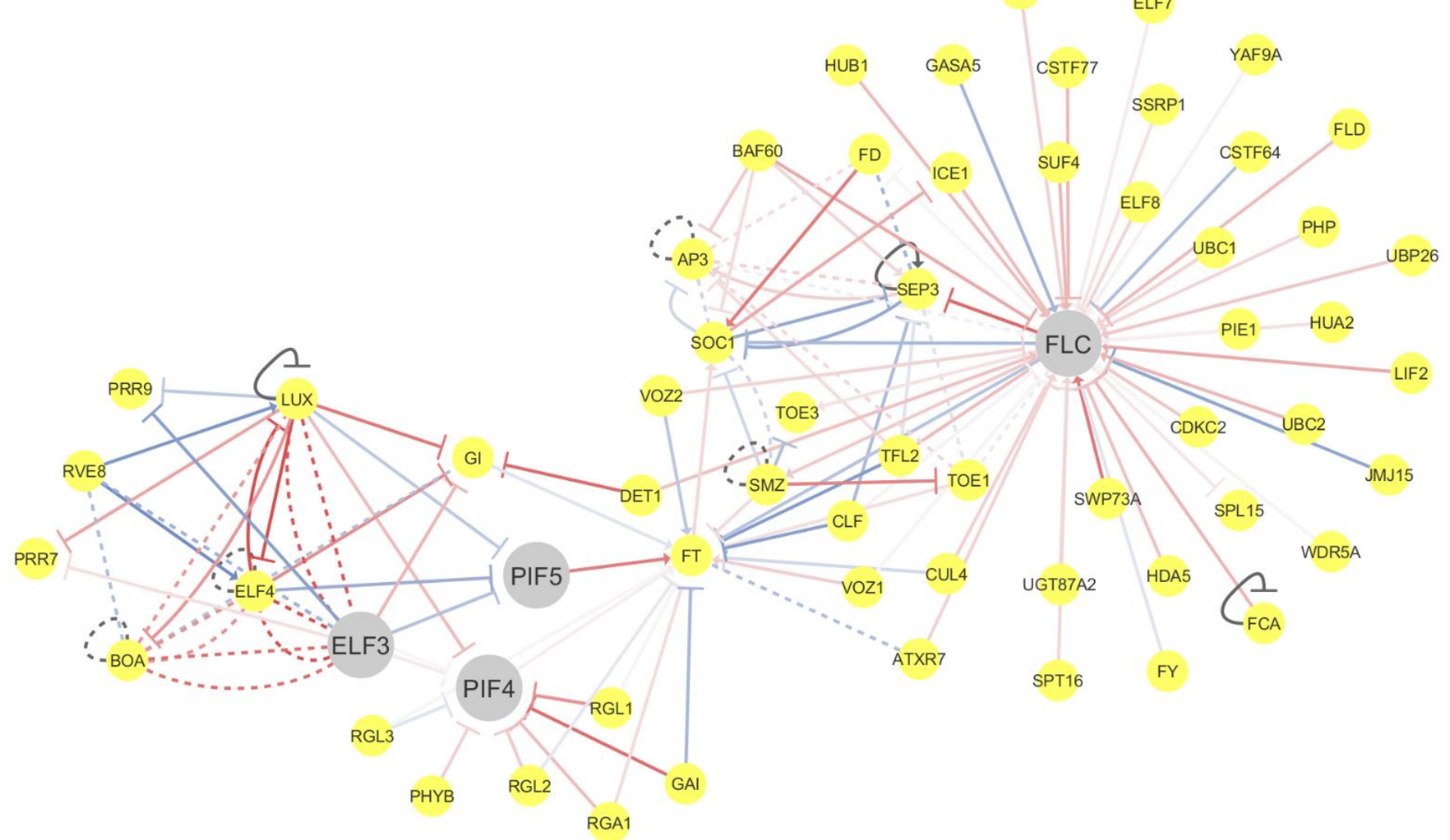

(b)

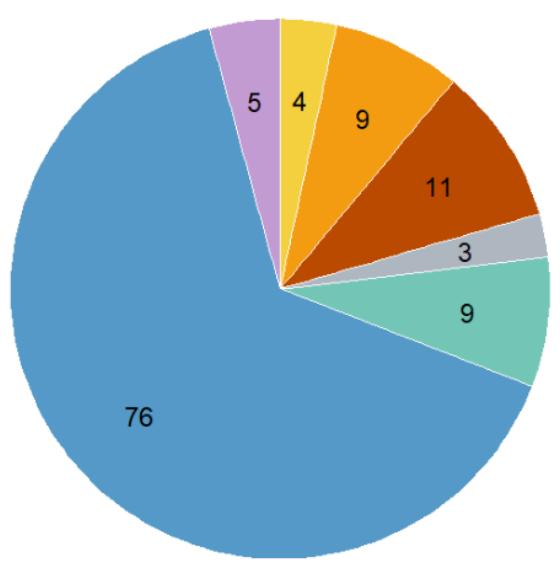

(c)
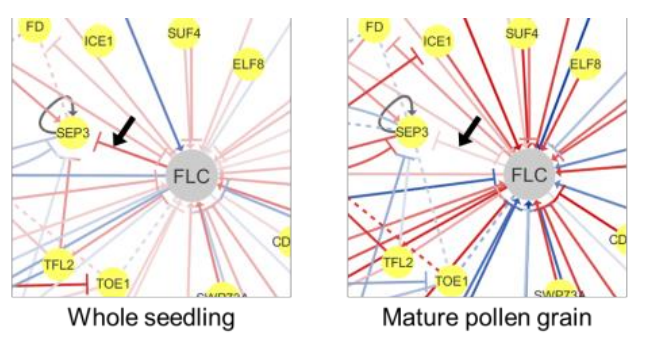

Known:

Known: Auto

Unknown: Commo

Unknown: Tissue

Unknown: Auto
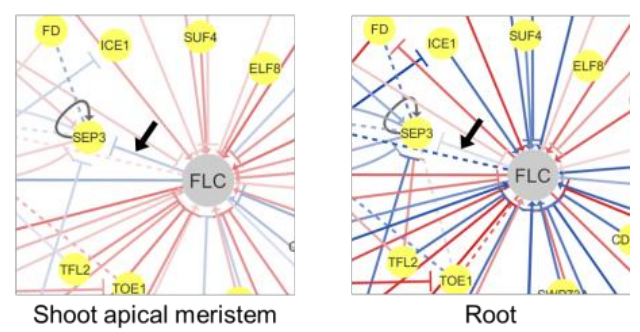
bioRxiv preprint doi: https://doi.org/10.1101/2020.10.22.348540; this version posted October 22, 2020. The copyright holder for this preprint (which was not certified by peer review) is the author/funder, who has granted bioRxiv a license to display the preprint in perpetuity. It is made available under aCC-BY-NC-ND 4.0 International license.

\section{FIGURE 7}
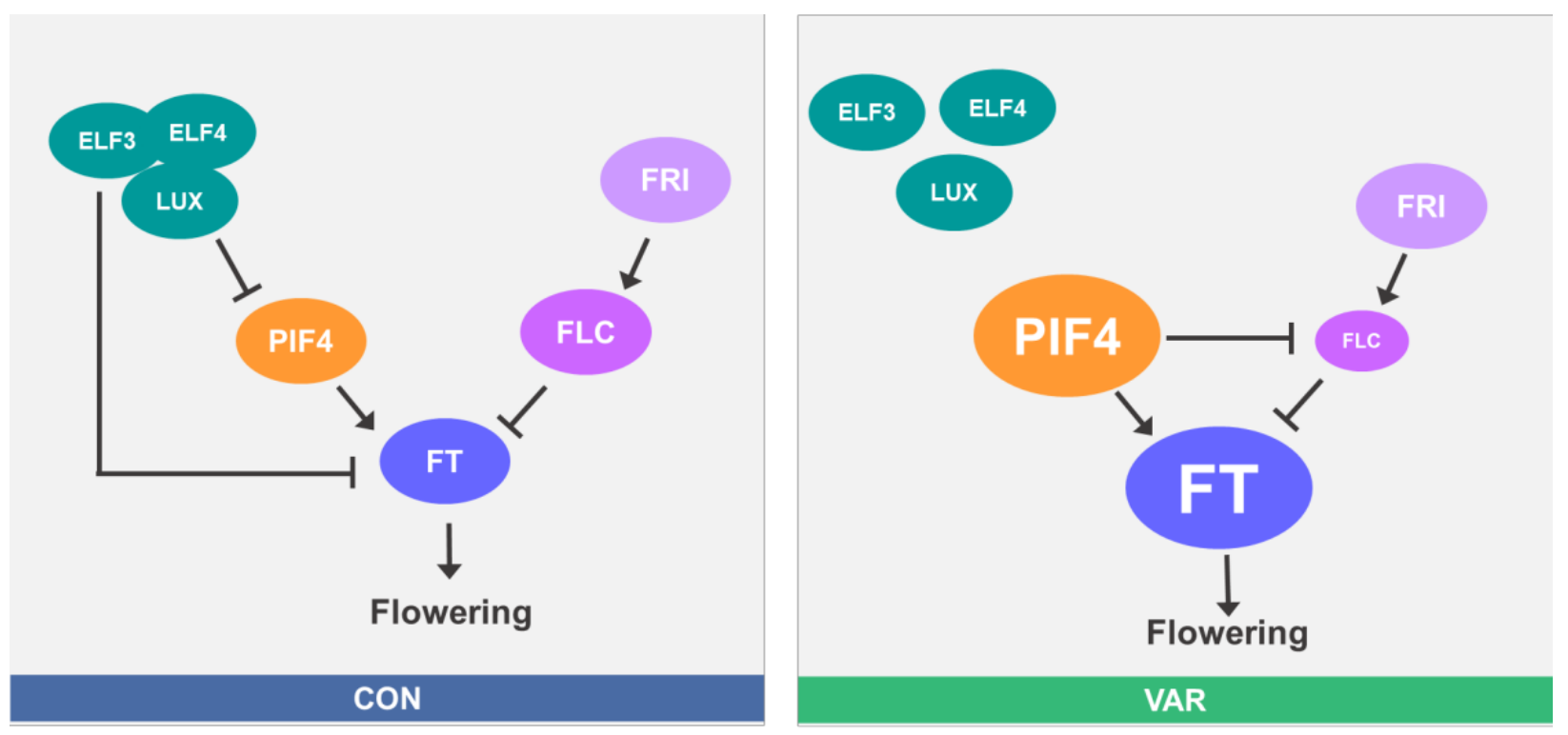
bioRxiv preprint doi: https://doi.org/10.1101/2020.10.22.348540; this version posted October 22, 2020. The copyright holder for this preprint (which was not certified by peer review) is the author/funder, who has granted bioRxiv a license to display the preprint in perpetuity. It is made available under aCC-BY-NC-ND 4.0 International license.

Jenkitkonchai et al., 2020

\section{Supplementary Figures}
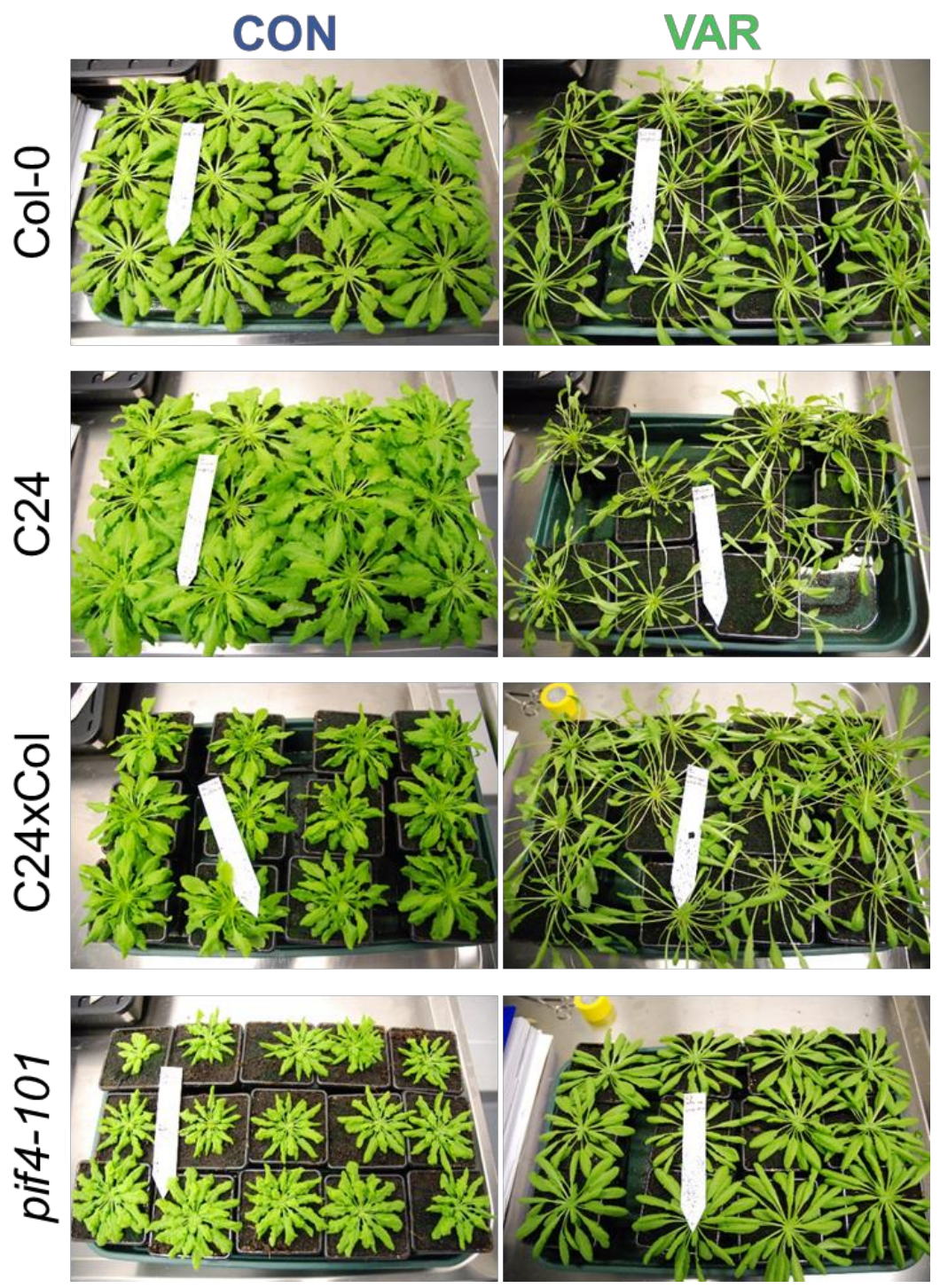

FIGURE S1 Phenotypic changes in Arabidopsis thaliana in response to daily variable temperature. The Col0, C24, C24xCol and pif4-101 plants grown at either constant temperature of $22^{\circ} \mathrm{C}(\mathrm{CON})$ or variable temperature (VAR) under the short-day (SD) condition at 70 days after sowing. 
(a)

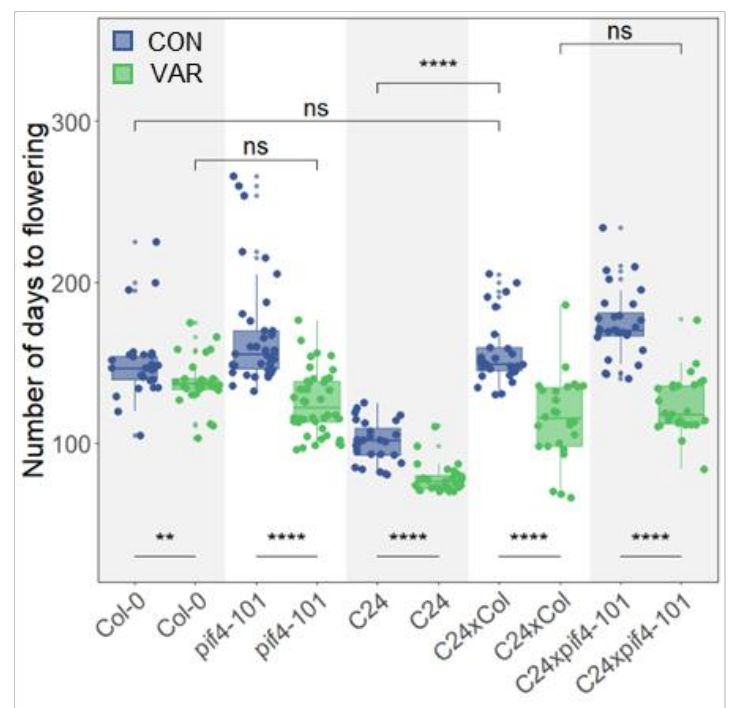

(b)

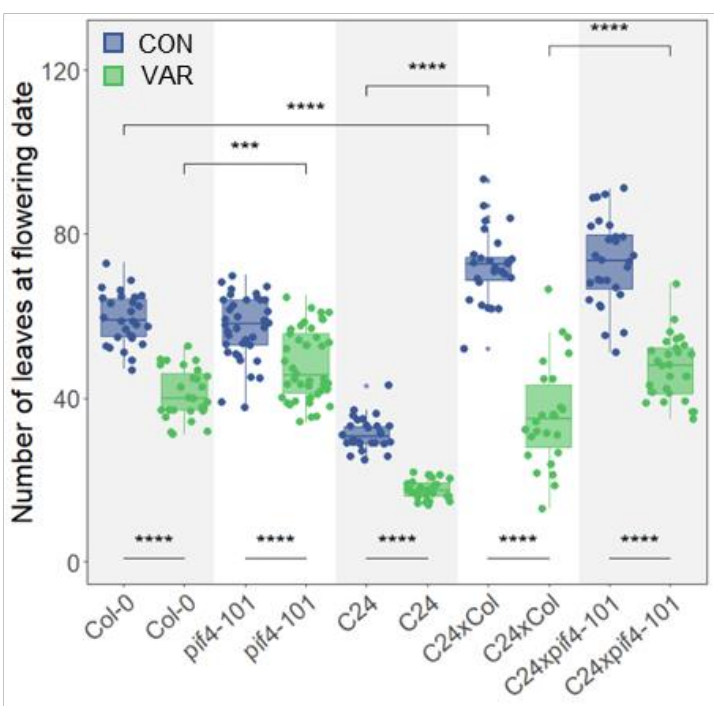

FIGURE S2 The second biological replicate of the flowering time results shown in Figure 1c, d. (a) Boxplots showing the total number of days to flowering of the plants grown under the CON (Blue) and VAR conditions (Green). (b) Boxplots showing the total number of rosette leaves at flowering days. Solid lines inside the boxes represent medians. Each dot represents data from each plant. There were 26 and 42 plants per line per condition. Statistical test between the two groups was computed by Wilcoxon rank sum test, $p \leq 0.0001$ $(* * * *), p \leq 0.001\left(^{* * *}\right), p \leq 0.01(* *), p \leq 0.05\left(^{*}\right)$ and $p>0.05$ (ns). 
bioRxiv preprint doi: https://doi.org/10.1101/2020.10.22.348540; this version posted October 22, 2020. The copyright holder for this preprint (which was not certified by peer review) is the author/funder, who has granted bioRxiv a license to display the preprint in perpetuity. It is made available under aCC-BY-NC-ND 4.0 International license.

(a)

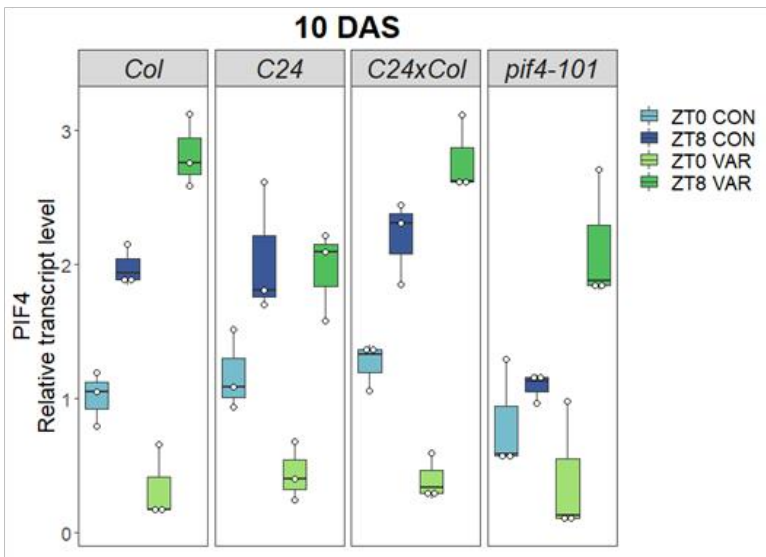

(b)

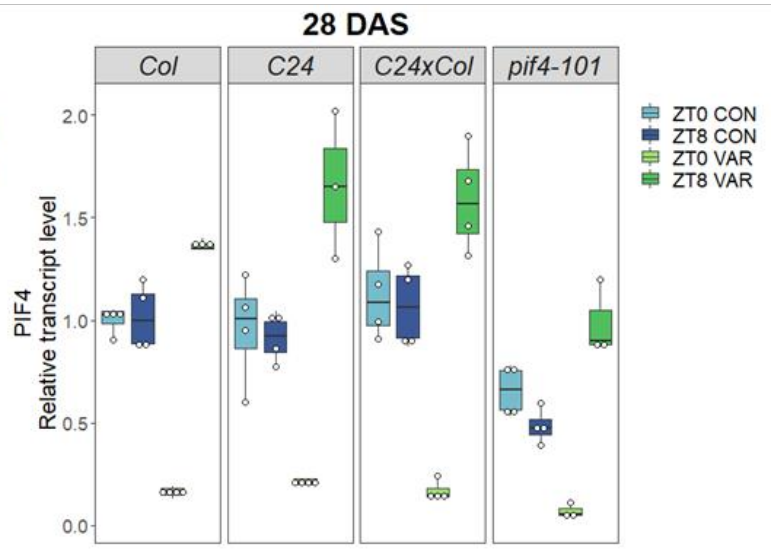

FIGURE S3 Dynamic changes of transcript levels of PIF4 under the constant and variable temperature conditions. Boxplots showing the relative expressions of PIF4 of Col-0, C24, C24xCol and pif4-101 from 3-4 individual plants normalized to the average of transcription level of Col-0 CON ZTO (control). (a) PIF4 at 10 DAS and (b) PIF4 at 28 DAS. The primers used were PIF4_6581/PIF4_6582. These primers were designed to amplify the sequence upstream to the position of T-DNA insertion in the pif4-101 mutant line. White dots represent different individual plants. Black lines inside the boxes represent medians. 
bioRxiv preprint doi: https://doi.org/10.1101/2020.10.22.348540; this version posted October 22, 2020. The copyright holder for this preprint (which was not certified by peer review) is the author/funder, who has granted bioRxiv a license to display the preprint in perpetuity. It is made available under aCC-BY-NC-ND 4.0 International license.

(a)

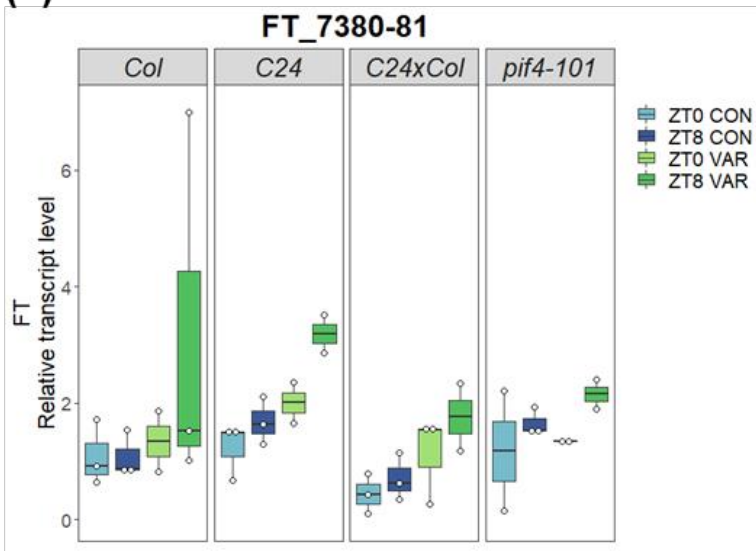

(b)

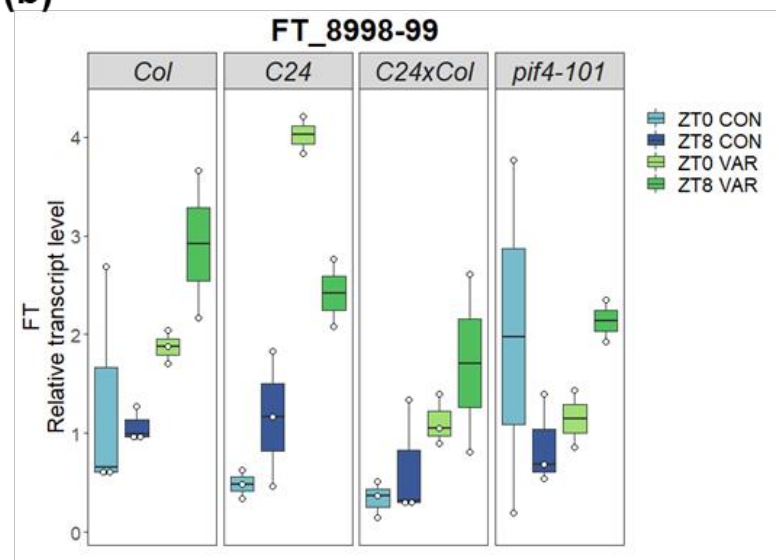

FIGURE S4 Dynamic changes of transcript levels of FT under the constant and variable temperature conditions. Boxplots showing the relative expressions of FT at 10 DAS of Col-0, C24, C24xCol and pif4-101 from 2-4 individual plants normalized to the average of transcription level of Col-0 CON ZTO (control). The primers used were (a) FT_7380/FT_7381 and (b) FT_8998/FT_8999. White dots represent different individual plants. Black lines inside the boxes represent medians. 
bioRxiv preprint doi: https://doi.org/10.1101/2020.10.22.348540; this version posted October 22, 2020. The copyright holder for this preprint (which was not certified by peer review) is the author/funder, who has granted bioRxiv a license to display the preprint in perpetuity. It is made available under aCC-BY-NC-ND 4.0 International license.

(a)

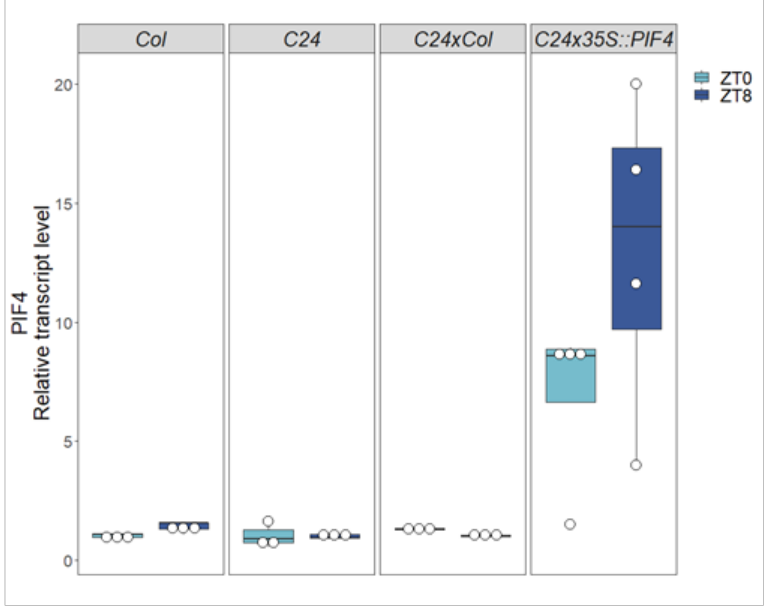

(b)

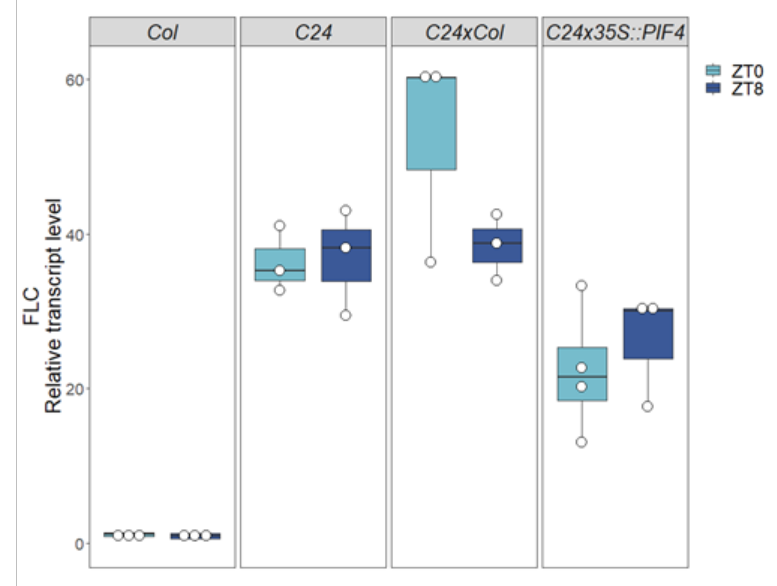

(c)

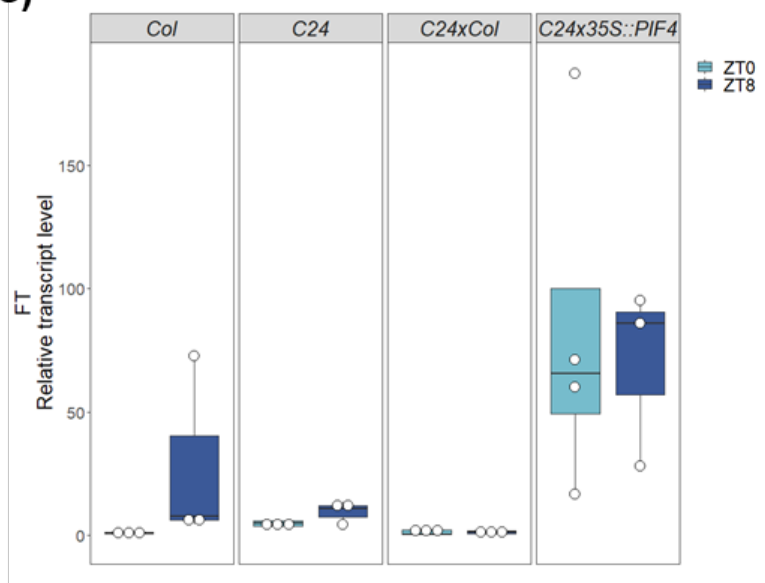

FIGURE S5 Overexpression of PIF4 resulted in the elevated transcription levels of $F T$ in older plants (28 DAS). (a-c) Boxplots showing relative expressions of flowering related-genes namely, PIF4 (the primers used were PIF4_6581/PIF4_6582), FLC and FT (the primers used were FT_7380/FT_7381) of plants grown under constant $22^{\circ} \mathrm{C}$ at 28 -day after sowing (28 DAS) from 3 individual plants, normalized to the average transcription level of Col-0 ZTO (control). White dots represent different individual plants. 
bioRxiv preprint doi: https://doi.org/10.1101/2020.10.22.348540; this version posted October 22, 2020. The copyright holder for this preprint (which was not certified by peer review) is the author/funder, who has granted bioRxiv a license to display the preprint in perpetuity. It is made available under aCC-BY-NC-ND 4.0 International license.

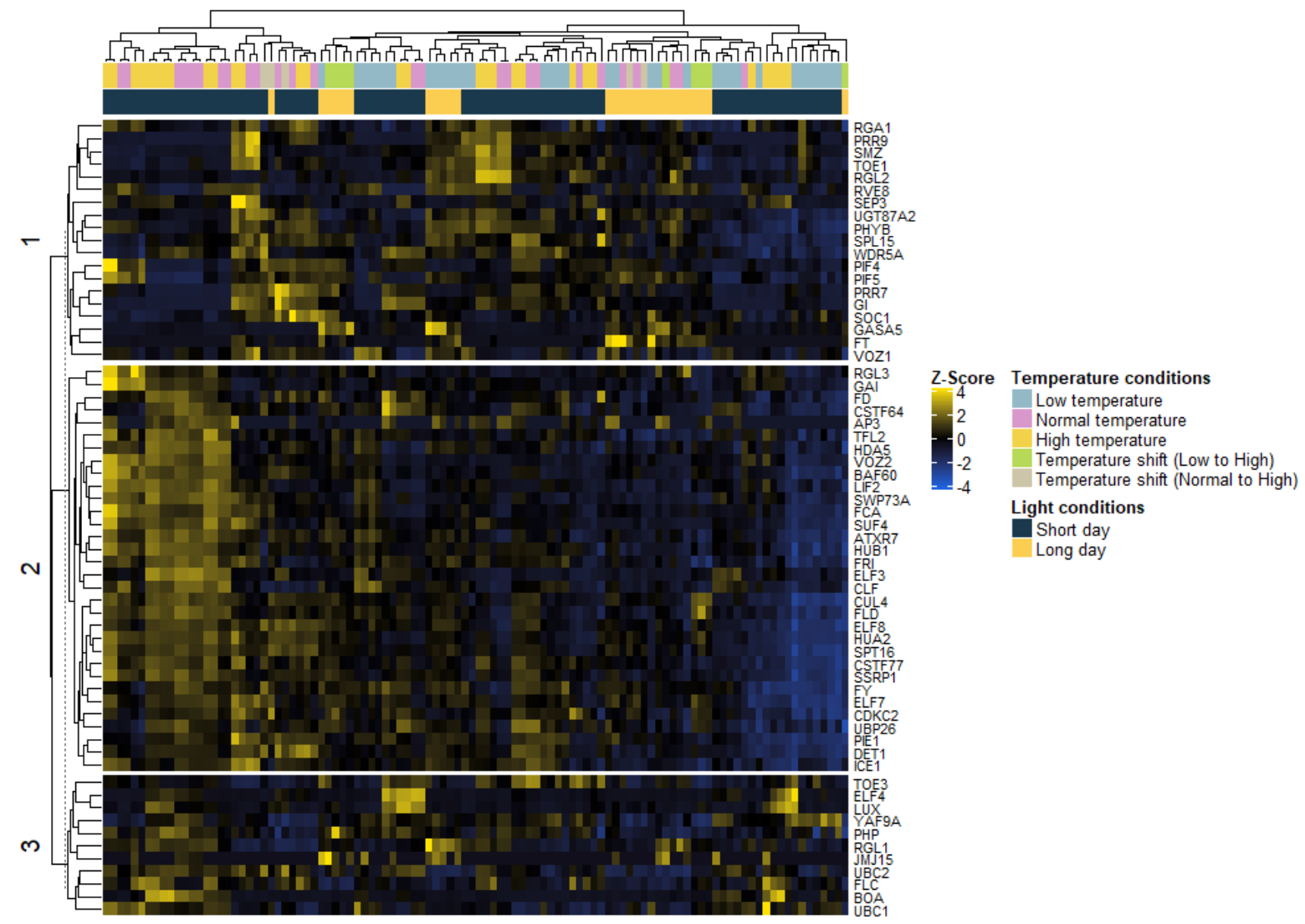

FIGURE S6 Transcriptional patterns of flowering genes in whole seedlings. Heatmap showing the transcriptional patterns of 62 flowering-time-relating genes, namely PIF4, PIF5, ELF3, FLC and their immediate up- and downstream genes from whole seedlings of Arabidopsis thaliana ecotype Col-0 grown under different temperature and light conditions (from the studies by Cortijo et al., 2017, Dickinson et al., 2018, Tasset et al., 2018, Zhu et al., 2015, Ezer, Shepherd, et al., 2017 and Ezer, Jung, et al., 2017). Z-scores of TPM values were calculated across the samples. Yellow indicates relative up-regulation and blue indicates down-regulation. 
bioRxiv preprint doi: https://doi.org/10.1101/2020.10.22.348540; this version posted October 22, 2020. The copyright holder for this preprint (which was not certified by peer review) is the author/funder, who has granted bioRxiv a license to display the preprint in perpetuity. It is made available under aCC-BY-NC-ND 4.0 International license.

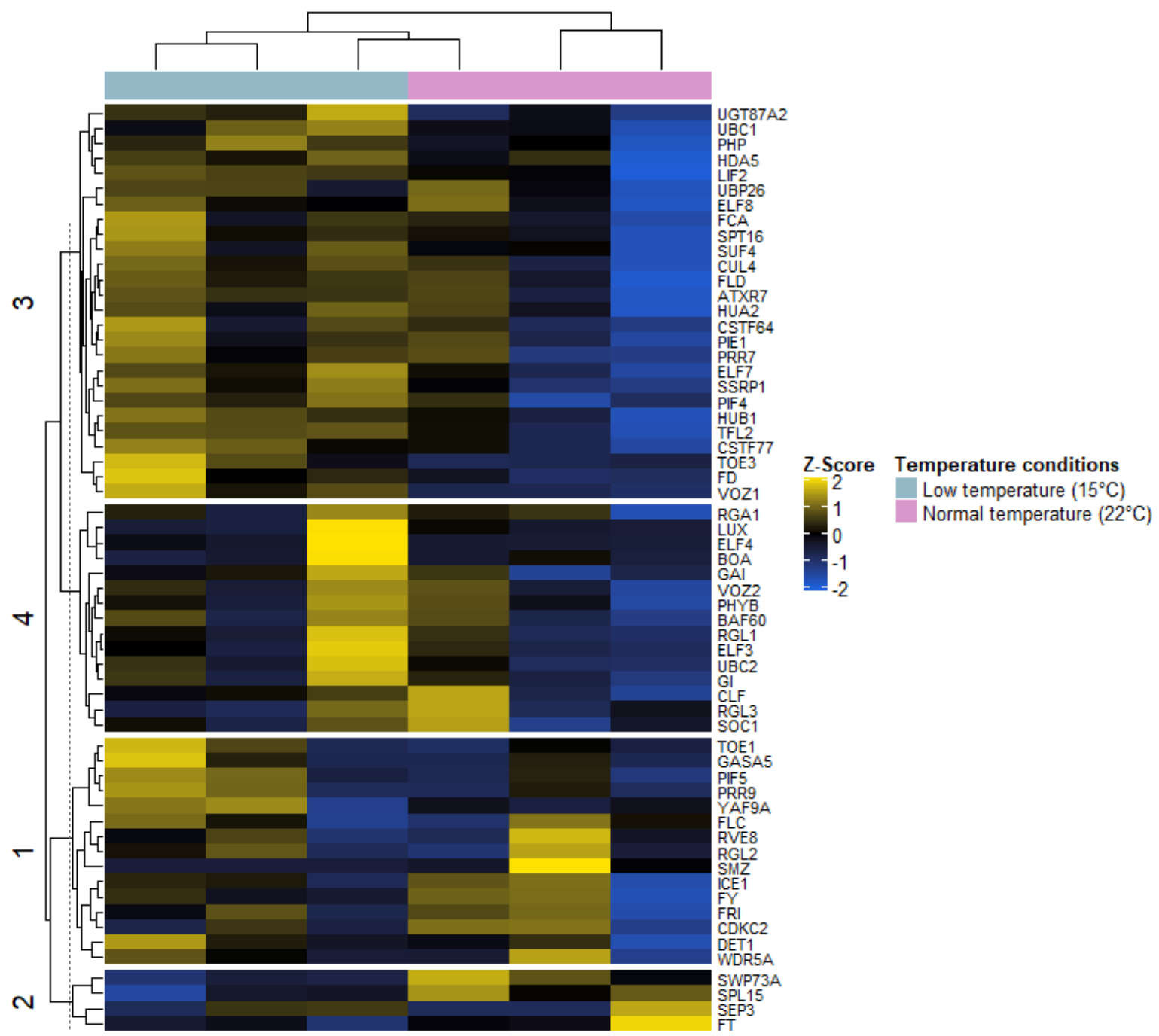

FIGURE S7 Transcriptional patterns of flowering genes in rosette leaves. Heatmap showing the transcriptional patterns of 62 flowering-time-relating genes, namely PIF4, PIF5, ELF3, FLC and their immediate up- and downstream genes from rosette leaves of Arabidopsis thaliana ecotype Col-0 grown under different temperature and light conditions (from the studies by Durufle et al., 2017). Z-scores of TPM values were calculated across the samples. Yellow indicates relative up-regulation and blue indicates downregulation. 
bioRxiv preprint doi: https://doi.org/10.1101/2020.10.22.348540; this version posted October 22, 2020. The copyright holder for this preprint (which was not certified by peer review) is the author/funder, who has granted bioRxiv a license to display the preprint in perpetuity. It is made available under aCC-BY-NC-ND 4.0 International license.

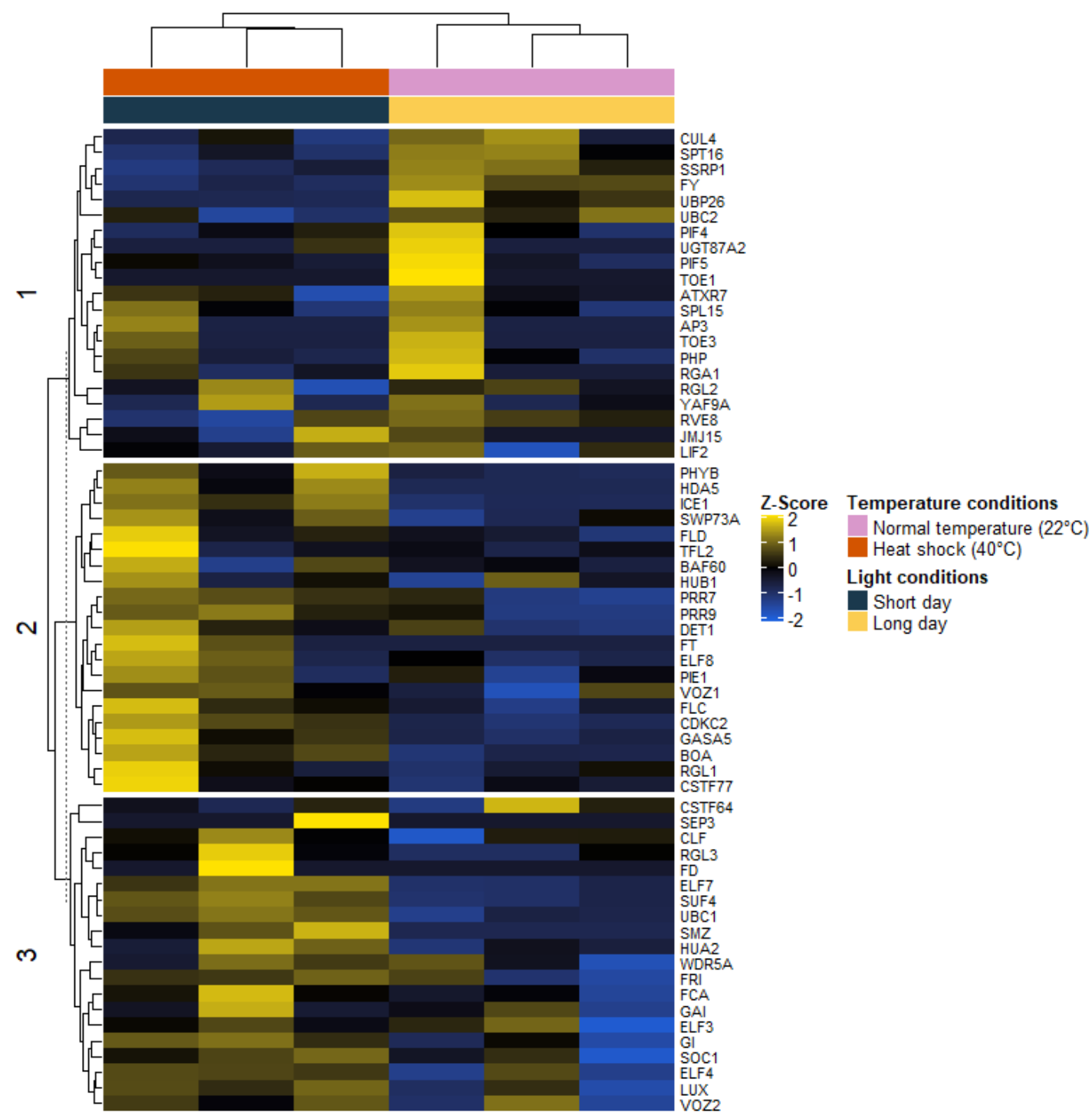

FIGURE S8 Transcriptional patterns of flowering genes in mature pollen grain. Heatmap showing the transcriptional patterns of 62 flowering-time-relating genes, namely PIF4, PIF5, ELF3, FLC and their immediate up- and downstream genes from mature pollen grain of Arabidopsis thaliana ecotype Col-0 grown under different temperature and light conditions (from the studies by Rahmati Ishka et al., 2018). Zscores of TPM values were calculated across the samples. Yellow indicates relative up-regulation and blue indicates down-regulation. 
bioRxiv preprint doi: https://doi.org/10.1101/2020.10.22.348540; this version posted October 22, 2020. The copyright holder for this preprint (which was not certified by peer review) is the author/funder, who has granted bioRxiv a license to display the preprint in perpetuity. It is made available under aCC-BY-NC-ND 4.0 International license.

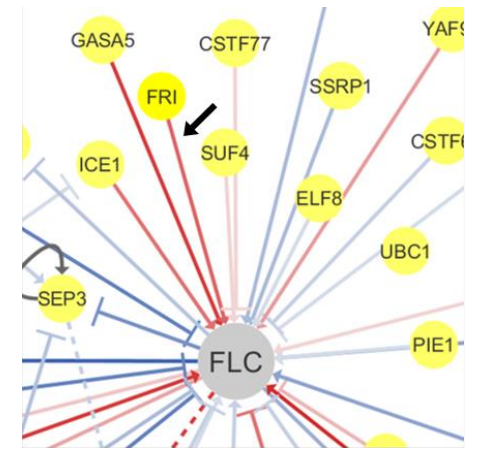

Rosette leaves

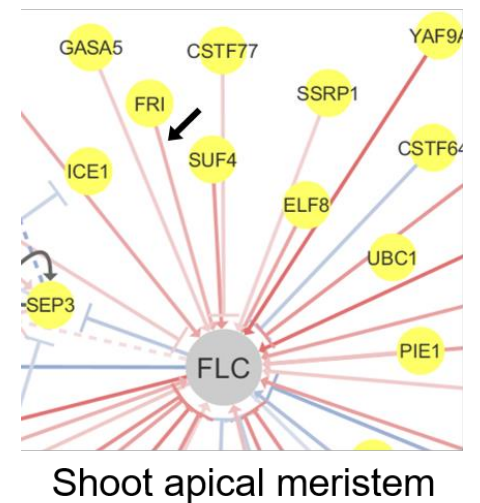

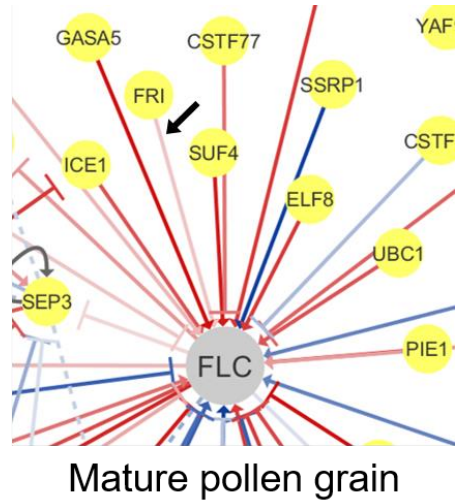

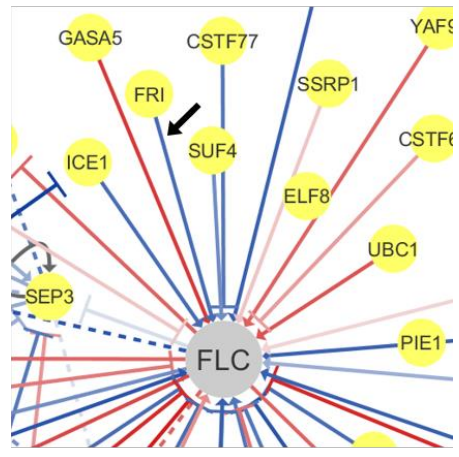

Root

FIGURE S9 The FRI might positively regulate the FLC expression in tissue-specific manner. The networks showing the expression correlations which were calculated from individual tissues namely, rosette leaves, mature pollen grain, shoot apical meristem (SAM) and root. Edge colors represent the correlation coefficients: positive (red) and negative correlation (blue), using Spearman's correlation coefficient method. Lower correlation values are shown as paler-color edges and higher correlation values as darkercolor edges. Solid/dashed black lines represent the auto-regulation. Black arrows indicate the gene pair of interest. 